\title{
ROZDZIALY
}

\author{
Anna Aneta Tomczak
}

\section{Ewolucja zasad obszarowej ochrony krajobrazu miejskiego w polskich działaniach planistycznych}

Zarys treści: W rozdziale przedstawiono najważniejsze etapy powstawania zasad ochrony obszarowej w dokumentach rozwojowych miast. Proces tworzenia podstaw prawnych oraz stosowanych praktyk rozpoczął się w momencie odzyskania niepodległości przez Polskę w 1918 roku, czyli z początkiem okresu międzywojennego charakteryzującego się intensyfikacją dążeń do formalnego usankcjonowania ochrony dziedzictwa narodowego. W okresie powojennym bardzo ważną rolę odegrały opracowania historyczno-urbanistyczne, w których dokumentowano etapy rozwoju jednostek osadniczych i waloryzowano ich wartości kulturowe. Momentem przełomowym w ochronie historycznej struktury miast były lata 60. i 70. XX wieku, kiedy w praktyce urbanistycznej wprowadzono obszarowe strefy ochrony konserwatorskiej oraz zasady tworzenia wytycznych rozwojowych do formalnych dokumentów planistycznych. Podejście obszarowe występuje również we współczesnych kierunkach rozwoju miast i zasadach opracowywania miejscowych planów zagospodarowania przestrzennego.

Słowa kluczowe: krajobraz miasta, dziedzictwo kulturowe, planowanie przestrzenne.

\section{Wprowadzenie}

Celem ochrony dziedzictwa kulturowego miasta jest zachowanie wartości materialnych, będących świadectwem działań poprzednich pokoleń, w jego strukturze przestrzennej. Można je odnaleźć w pojedynczych budynkach, całych zespołach budowlanych, układzie rozplanowania miasta, a także w sposobie ukształtowania przestrzeni publicznych. Uchronione dziedzictwo, istniejące w staromiejskich układach przestrzennych, ma często również wartość niematerialną, która świadczy o rozwoju społecznym i gospodarczym jednostki osadniczej. Zachowanie tożsamości stanowi obowiązek współczesnego pokolenia, a ochrona przed przypadkowymi przekształceniami oraz właściwa kreacja stanowią priorytet w działaniach związanych z planowaniem i zarządzaniem zasobami miejskimi. 
Konstruowanie zasad ochrony poprzedza się badaniami i waloryzacją istniejących wartości, do których należy zaliczyć: układ zabudowy, elementy gospodarki nieruchomościami oraz ewolucję nawarstwień przestrzennych. Uzyskana w procesie inwentaryzacji i badań terenowych wiedza o kolejnych etapach rozwoju jednostki osadniczej oraz zmianach, jakie dokonały się w okresie jej funkcjonowania, pozwala na wskazanie najważniejszych elementów w układzie przestrzennym, które należy zachować i chronić przed przypadkowymi przekształceniami. Odpowiednia identyfikacja wartości istniejących w strukturze miasta, a następnie jej właściwa waloryzacja są niezbędne w procesie planowania jego rozwoju. W miejscach o wysokich walorach estetycznych, historycznych i przestrzennych szczególnie istotna jest zasada ,świadomego dodawania”. Wypracowanie właściwych proporcji pomiędzy ochroną i kreacją wymaga ścisłej współpracy specjalistów, posiadających wiedzę zarówno z zakresu geografii historycznej, jak i planowania oraz konserwatorstwa urbanistycznego.

Działania związane z ochroną obszarową zespołów staromiejskich oraz planowaniem ich przekształceń mają długą historię w polskiej praktyce konserwatorskiej i urbanistycznej. W historii występują okresy, kiedy priorytetem były początkowo inwentaryzacje zasobów kulturowych miast, potem badania rozwoju przestrzennego, a na końcu dokumentacje konserwatorskie i planistyczne. Zasady ochrony i kreacji krajobrazu miejskiego ewoluowały w czasie. Ich zakres i szczegółowość uzależnione były od sytuacji gospodarczej kraju oraz indywidualnych potrzeb lokalnych, jednak wartością nadrzędną zawsze było zachowanie historycznej struktury miasta.

Ewolucja zasad obszarowej ochrony krajobrazu miejskiego przedstawiona została na wybranych przykładach graficznych z miasta Łodzi i okolic, ponieważ obszar centralnej Polski jest szczególnie bliski autorce. Omawiana problematyka i zakres merytoryczny dokumentów planistycznych, opracowywanych w latach 1918-2020, obejmuje jednak przekrojową tematykę występującą również na obszarach innych polskich miast.

\section{Początki ochrony obszarowej krajobrazów miejskich}

O początku ochrony obszarowej zabytków w Polsce można mówić już w $1918 \mathrm{r}$. Po odzyskaniu niepodległości zintensyfikowano dążenia do prawnego usankcjonowania ochrony odzyskanego dziedzictwa narodowego. Jan Pruszyński pisał, że „trudno w pełni zrozumieć, w jaki sposób w kraju zniszczonym [...], którego państwowość kształtowały metody, wyobrażenia i uprzedzenia wyniesione z trzech różnych systemów polityczno-społecznych można było od razu przystąpić [...] do działalności ochronnej skalą i zasięgiem przewyższającej często późniejsze dokonania" (Pruszyński 1988: 75). 
Aktywność w zakresie czynności związanych z ochroną dziedzictwa kulturowego w wolnej Polsce była możliwa dzięki organizacjom społecznym, stowarzyszeniom oraz działalności, jaką prowadzono jeszcze przed odzyskaniem niepodległości (Zalasińska 2010; Szymaniec 2017). Działaniom związanym z kształtowaniem miast i ochroną zabytków na terenach zaborów najbardziej sprzyjała polityka austriacka. Od 1880 roku w Krakowie funkcjonowało stowarzyszenie naukowców różnych specjalności pod nazwą Grono Konserwatorów Galicji Zachodniej. Równocześnie we Lwowie powstało Grono Konserwatorów Galicji Wschodniej. Wiele specjalistycznych prac z zakresu historii architektury, urbanistyki i konserwacji upubliczniono w formie opracowań, tzw. Tek Konserwatorskich, które kształtowały świadomość społeczną i propagowały wiedzę dotyczącą polskich wartości przestrzennych (Teki są obecnie dostępne w Jagiellońskiej Bibliotece Cyfrowej). Na przełomie XIX i XX wieku organizowano seminaria i zjazdy konserwatorskie ziem Galicji1, podczas których wymieniano poglądy oraz doświadczenia związane z wartościami architektonicznymi w miastach i ochroną zabytków. Na terenach zaboru rosyjskiego od 1906 roku działało Towarzystwo Opieki nad Pamiątkami Historycznymi i Zabytkami Sztuki i Kultury Polskiej, przekształcone następnie w Towarzystwo Opieki nad Zabytkami Przeszłości, którego celem była ochrona materialnego dziedzictwa narodowego (Kowalczyk 1978). Z punktu widzenia kształtowania miast znaczną zasługą Towarzystwa była działalność pomiarowo-architektoniczna oraz inwentaryzacyjna (wykonano 18 tys. klisz). Stowarzyszenia oraz organizacje działające w czasach zaborów wypracowały podstawy metodyczne i zręby prawne, które po 1918 roku stanowiły doskonały początek kształtowania przestrzeni w miastach i ochrony wartości zabytkowych w odradzającym się państwie polskim.

Dokumentem o szczególnym znaczeniu dla kształtowania krajobrazu miejskiego był pierwszy akt prawny z 1918 roku, czyli Dekret Rady Regencyjnej o opiece nad zabytkami sztuki i kultury ${ }^{2}$. Wśród obiektów podlegających ochronie, poza indywidualnymi budowlami, dokument ten wymieniał ,grupy budynków wybitne pod względem estetycznym i znamienne bądź dla całych miast, osad, wsi bądź dla ich dzielnic” oraz „na gruncie dochowane do dziś rozplanowania starych miast i dzielnic staromiejskich wraz z dawnymi, historycznymi nazwami ulic i placów". Były to pierwsze zapisy prawne pozwalające na szczególne traktowanie wartości historycznych w skali już nie tylko pojedynczego zabytku,

\footnotetext{
${ }^{1}$ Grona Konserwatorów Galicji Zachodniej i Wschodniej zorganizowały pięć wspólnych zjazdów - pierwszy w 1888 roku w Krakowie, drugi w 1890 roku we Lwowie, trzeci w 1891 roku w Krakowie, czwarty w 1904 roku w Przemyślu i piąty w 1910 roku ponownie w Krakowie. Z inicjatywy obu Gron w 1911 roku w Krakowie odbył się ponadto Pierwszy Zjazd Miłośników Zabytków Sztuki i Historii.

${ }^{2}$ Dekret Rady Regencyjnej o opiece nad zabytkami sztuki i kultury z 31 października 1918 roku (Dziennik Praw Państwa Polskiego z dnia 8 listopada 1918 roku, nr 16, poz. 36).
} 
ale również zespołu budynków, dzielnicy, a nawet całego miasta. Ochronie mogły również podlegać przestrzenie wokół zabytku, widoki na obiekt zabytkowy z dalszej perspektywy, a nawet panoramy zespołów historycznych miast. Zastosowanie cytowanego zapisu ustawowego dążyło do wykreowania idealistycznego obrazu panoramy miasta oraz zasad jej kształtowania w planach opracowanych w okresie międzywojennym. Przykładem jest zapis graficzny w Planie Zabudowy Miasta Lodzi ${ }^{3}$ (ryc. 1). Obraz miasta „z zewnątrz”, choć utopijny, był wyrazem potrzeby myślenia o mieście w skali całej jednostki osadniczej.

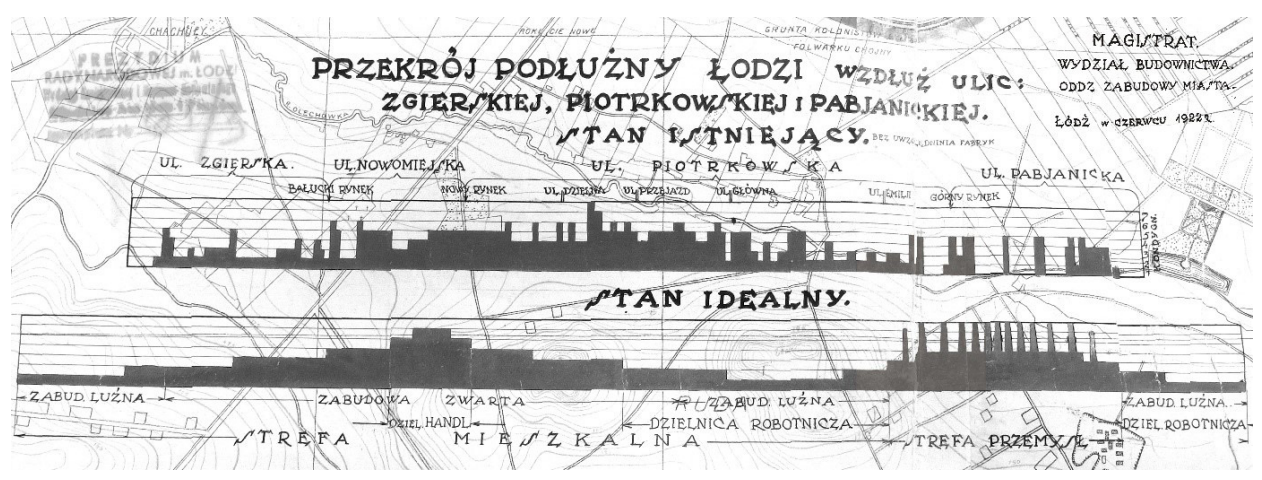

Ryc. 1. Panorama miasta dziś i jutro - Plan Zabudowy Miasta Łodzi (analiza do planu według wysokości kondygnacji, dane na rok 1920, skala 1:10000). Schemat przedstawia utopijne dążenie do segregacji funkcjonalnej w mieście oraz jej wpływu na kształtowanie panoramy widokowej z charakterystycznymi łódzkimi kominami

Autor: Magistrat, Wydział Budownictwa, Oddział Zabudowy Miasta, Łódź

Data opracowania: $1922 \mathrm{r}$.

Źródło: Archiwum Państwowe w Łodzi, Zbiory Ikonograficzne (syg. 61/3)

W przestrzennym odbiorze zabytków istotne były zasady ich postrzegania w otaczającej przestrzeni oraz widoku z zabytku na otaczający krajobraz. Artykuł 17. cytowanego Dekretu ustalał, że „Rząd ma prawo nie dopuścić do niszczenia, zasłaniania lub szpecenia widoku na zabytki lub z zabytków nieruchomych”. Istniała więc podstawa prawna pozwalająca chronić zarówno indywidualne budynki, jak i zespoły zabytkowe w ich otoczeniu historycznym. Dekret nie ustalał jednak zasad określania stref ochrony ekspozycyjnej w skali miejskiej. Mogły być one przyjmowane indywidualnie dla każdego obiektu lub zespołu obiektów, które podlegały ochronie (Pruszyński 1989), co oceniano przed przystąpieniem

\footnotetext{
${ }^{3}$ Plan Zabudowy Miasta Łodzi został przyjęty w 1930 roku przez Radę Miejską uchwałą nr VII z 24 czerwca 1930 roku. Następnie został poddany ocenie na szczeblu administracji ministerialnej. Został zaakceptowany decyzją Komisarza Rządowego Miasta Łodzi 30 marca 1934 roku. Ostatecznie jednak dopiero 28 marca 1935 roku zatwierdziło go Ministerstwo Spraw Wewnętrznych (bez fragmentów, które wyłączono na skutek protestu przemysłowców łódzkich w trakcie upublicznienia dokumentacji Planu).
} 
do prac restauratorskich w zabytku oraz jego otoczeniu. Przy ocenie krajobrazowej uwzględniano dwa najważniejsze uwarunkowania: czynnik lokalizacyjny i sytuacyjny (czyli lokalizację i naturalne ukształtowanie terenu wokół zabytku) oraz czynnik prawny, obejmujący otoczenie określone granicami i strukturą własności (Tomczak 2018). Dekret uzależniał wszelkie zmiany w zabytku oraz wokół niego od decyzji lokalnych władz posiadających odpowiednie architektoniczne i konserwatorskie przygotowanie zawodowe. Zabytki nieruchome i ich otoczenie podlegały więc odpowiedniemu nadzorowi konserwatorskiemu.

Zabytki nieruchome nie mogły być „,burzone, niszczone, przerabiane, rekonstruowane, zdobione lub uzupełniane [...] bez uprzedniego pozwolenia odpowiedniej władzy konserwatorskiej”. Z punktu widzenia ochrony zabytków w skali krajobrazowej najważniejszy był jednak zapis cytowanego Dekretu w art. 13: „Takież pozwolenie nieodzowne jest przy wszystkich zmianach, zamierzonych w najbliższym otoczeniu ważniejszych zabytków nieruchomych". Przepis prawa uwzględniał wprawdzie „ważniejsze” zabytki, ale nie precyzował dokładnie ich skali przestrzennej. Za zabytek uznać można więc było i pojedynczy budynek, i zespół budynków ${ }^{4}$. Objęcie terenów wokół budynków stanowiących ,świadectwo kultury i sztuki" miało szczególnie znaczenie w odbiorze zabytków w skali urbanistycznej.

W procesie planowania przestrzennego na początku XX wieku zauważano potrzebę planowania miasta jako całości. Jak pisał Ignacy Drexler: ,[...] Dobry projekt powstanie tylko przy wyczerpującym uwzględnieniu kształtów wybranego terenu, otoczenia budowlanego i roślinnego. Budynek miejski nie jest przedmiotem zupełnie indywidualnym, ale, jak klejnot w koronie, jest tylko częścią większej, złożonej całości. Można się zajmować ochroną pojedynczych klejnotów, ale przez to nie zrozumie się jeszcze całej korony" (Drexler 1921: 287).

Pojmowanie miasta jako całej jednostki wskazywano w procesach planistycznych i opracowywanych ówcześnie planach regulacyjnych (Lewicki 2016). W dyskusji dotyczącej zasad budowy miast wybrzmiewała jednak mocna krytyka kierunków przyjmowanych w planach opracowywanych dla układów osadniczych na początku XX wieku. Wprowadzano w nich zasady przyświecające poprawie jakości życia w miastach, co z punktu widzenia warunków społecznych było niezwykle cenne, ale w zakresie działań przestrzennych często prowadziło do nieodwracalnych przekształceń wartościowych historycznych układów miejskich. Projektowano szerokie, proste ulice, przystosowane do rosnących potrzeb motoryzacyjnych i nowych warunków dobrego doświetlenia mieszkań, prowadzono reparcelację działek budowlanych w centrach miast, w celu stworzenia przestrzeni wspólnych i bardziej przestronnych oraz wprowadzano nowe układy bloków

${ }^{4}$ Dekret Rady Regencyjnej z 31 października 1918 roku w art. 11 ustalał, że ,,wszelkie nieruchome [...] dzieła, świadczące o sztuce i kulturze epok ubiegłych [...] korzystają z opieki prawa, zanim wpisane zostaną do inwentarza zabytków sztuki i kultury”. 
budowlanych o regularnych kształtach, które wpływały na zmiany przestrzenne i bezpowrotnie zacierały historyczne cechy rozplanowania układów miejskich.

„Dotychczas popełniono u nas względem starych dzielnic ciężkie grzechy. Niszczono bez potrzeby ich zabytkowe piękno, prostując niepotrzebnie ulice, wyrównując dawne place i znosząc całe bloki artystycznie cennych domostw. Tymczasem w latach wojny zniszczało tak wiele, iż skrupulatniej chronić musimy spuściznę dawnych czasów. [...] U nas ochrona poszczególnych zabytków znalazła pewne zrozumienie i poparcie - ale niestety, nie podnoszono dotychczas konieczności ochrony zabytków piękna dawnych wieków, pozostawionego w układzie ulic, placów i dzielnic [...]" - pisał w 1916 roku Roman Feliński (1916: 102). Rodziła się zatem potrzeba formułowania zasad ochrony obszarowej wartości przestrzennych historycznych układów urbanistycznych.

\section{Definiowanie pojęć prawnych w odbiorze wizualnym miast}

Polskie prawo międzywojenne definiowało wiele pojęć związanych z ochroną otoczenia wokół zabytków. W 1918 roku, w art. 14 cytowanego Dekretu wprowadzono pojęcie odległości wizualnej jako miary odbioru przestrzennego zabytku, wokół którego konserwator miał przywilej decyzyjny. Posiadał on „prawo wstrzymania wszelkich robót, wykonywanych bez zezwolenia lub niewłaściwie [...]", w tym również wokół budynku w odległości wizualnej. Było to jednoznaczne z wpływem konserwatora na zewnętrzny odbiór estetyczny zabytku i całego zespołu. Niewypełnianie ustaleń Rady Regencyjnej, w tym nakazów konserwatorskich, groziło sankcjami karnymi. W Dekrecie w art. 34 wskazywano zakres kary: „Winni przekroczenia przepisów ustawy niniejszej (w tym również dotyczących przesłaniania zabytków - dop. autorki) ulegną w drodze sądowej karze 3 miesięcy aresztu [...]".

W 1928 roku regulacje prawne dotyczące ochrony zabytków zostały zmodyfikowane, a kompetencje prawne podzielono na dwa akty ustawodawcze. Zakres legislacyjny ochrony otoczenia zabytków ustanawiały przepisy Rozporządzenia Prezydenta Rzeczypospolitej o opiece nad zabytkami ${ }^{5}$, natomiast kompetencje kształtowania przestrzeni określały przepisy Rozporzadzenia Prezydenta Rzeczypospolitej o prawie budowlanym i zabudowaniu osiedli ${ }^{6}$.

Przepisy Rozporzadzenia o opiece nad zabytkami w art. 2 zawęziły ekspozycyjny odbiór zabytku nieruchomego jedynie do otoczenia budowli. Definiowanie odbioru wizualnego, które wcześniejszy dekret nazywał widokiem na zabytek,

\footnotetext{
${ }^{5}$ Rozporządzenie Prezydenta Rzeczypospolitej z dnia 6 marca 1928 roku o opiece nad zabytkami (Dz.U., nr 29, poz. 265).

${ }^{6}$ Rozporzadzenie Prezydenta Rzeczypospolitej z dnia 16 lutego 1928 roku o prawie budowlanym i zabudowaniu osiedli (Dz.U., nr 23, poz. 202).
} 
zastąpiono określeniem otoczenie zabytku, które już w samym znaczeniu zawierało zdecydowanie mniejszy zakres obszarowy. Należy zauważyć, że otoczenie było związane z użytkowaniem bezpośredniego terenu wokół obiektu, często w granicach działki budowlanej, natomiast widok określał zewnętrzny kontekst krajobrazowy. Zmniejszało to zdecydowanie możliwość obszarowej ochrony zabytku w krajobrazie miejskim.

Kompetencje ochrony obszarowej zostały uwzględnione również w przepisach prawa budowlanego ${ }^{7}$, wydanych w 1928 roku. Przepisom ówczesnego prawa podlegała problematyka kształtowania przestrzeni wokół zabytku w odniesieniu do jego bezpośredniego otoczenia. Szczególnym przypadkiem była możliwość ustanowienia odpowiedniej służebności, którą w procesie przekształcania obszarów rolnych na tereny urbanizowane można było ustalać z uwzględnieniem prawa widoku ${ }^{8}$. Przepis ten odnosił się do terenów otwartych, pierwotnie wolnych od zabudowy i dopiero poddawanych nowej parcelacji. Miał on jednak znaczenie dla planowania przestrzeni w dużej skali odbioru, w szczególności panoram miejskich. Prawo widoku było, jak każda służebność, obciążone koniecznością poniesienia finansowych zobowiązań odszkodowawczych ${ }^{9}$, jednak dla układów miejskich możliwość ustanowienia takiej służebności krajobrazowej była precedensem w historii ochrony obszarowej zabytków. Podobne dopuszczenie nie wystąpiło już później, w powojennej Polsce, w prawodawstwie związanym z ochroną zabytków i kształtowaniem przestrzennym (Tomczak 2018).

W legislacji międzywojennej pojawiło się również pojęcie zeszpecenia krajobrazu, związane wprost z działaniami budowlanymi. Przepisy prawa budowlanego z 1928 roku w art. 337 wprowadzały zapis odnoszący się do miejscowości, ,w których krajobraz zasługuje na ochronę, właściwa władza może odmówić pozwolenia na budowę, przebudowę lub zmianę budynków, o ile by te roboty spowodowały zeszpecenie krajobrazu, a dałoby się tego uniknąć poprzez wybór innego miejsca [...]"10. Argumentując działania ochroną historycznych wartości przestrzennych, można było doprowadzić do wykreowania osi widokowej na zabytek, zachować wgląd na wartościowe elementy przestrzeni miejskiej czy po prostu odpowiednio kształtować ład przestrzenny.

${ }^{7}$ Ibidem, art. 81, art. 86, art. 337.

${ }^{8}$ Ibidem, art. 81 ustalał: „W wypadkach, gdy jest to konieczne dla przeprowadzenia scalenia [...] (w przypadku przekształcania terenu rolnego w teren urbanizowany - dop. autorki) mogą być ustanowione odpowiednie służebności, jak [...] prawo widoku [...]”.

${ }^{9}$ Ibidem, art. 86 ustalał: „Służebności ustanawiane w myśl art. 81 (w tym również „prawo widoku” - dop. autorki) powinny być wzięte pod uwagę przy ustalaniu dopłat i odszkodowań [...]".

${ }^{10}$ Ibidem, art. 337 ustalał: „Określenie miejscowości, w których ma być stosowany przepis $[. .$.$] przysługuje właściwemu wojewodzie”.$ 
Pojęcie miasta historycznego jako wartości przestrzennej wprowadzono w prawie polskim już w 1928 roku, a w 1936 roku uwzględniono w ochronie dziedzictwa kulturowego również „na gruncie dochowania rozplanowania starych miast i dzielnic staromiejskich"11, a także ich krajobrazu. Potrzeba obszarowej ochrony wybrzmiewała od początku kształtowania się zasad międzywojennej legislacji. W 1920 roku, w oficjalnej publikacji Ministerstwa Sztuki i Kultury, architekt Jarosław Wojciechowski wskazał kierunki działania w zakresie ochrony obszarowej miast i ich fragmentów: „Charakteru starych dzielnic naruszać nie wolno. Wszystko co w tych dzielnicach z konieczności ma być zrobione, wybudowane lub przebudowane, musi być podporządkowane pietyzmowi dla starożytniczej, historycznej i artystycznej wartości całego obszaru, nie wyłączając niwelety ulic oraz bruków i chodników, które nie powinny być podciągane pod ogólny szablon nowożytnego miasta" (Wojciechowski 1920: 12-13). Autor zwracał szczególną uwagę na regulowanie i zabudowywanie terenów sąsiadujących z zabytkami: „Zabytki powinny wpłynąć na charakter architektoniczny nie tylko ogólnego rozplanowania, lecz także i wyglądu zewnętrznego ważniejszych partii miasta, jak rynku, ulicy jakiejś, otoczenia kościoła itp. Prostota, spokój i wstrzemięźliwość w budowlach nowych stawianych w sąsiedztwie budowli zabytkowych to jedno z podstawowych praw opieki nad zabytkami" (Karczewski 1931: 24-28). W publikacji ministerialnej wyraźnie odstąpiono od ślepego naśladownictwa ustalonych form historycznych, przeciwnie - wskazywano potrzebę wprowadzania w tkankę miasta nowej, współczesnej myśli stylowej, z jednoczesnym poszanowaniem historycznego kontekstu miejsca.

W 1936 roku Ministerstwo Wyznań Religijnych i Oświecenia Publicznego wydało Okólnik o ochronie charakteru miast starych i dzielnic staromiejskich $^{12}$, w którym sformułowano zasady działania w przestrzeniach historycznych. W preambule podkreślono: „W zabytkowym zespole miasta starego czy dzielnicy staromiejskiej zabytkiem nie są same tylko budynki, ani nawet grupy, lecz również plan miasta w całości i w szczegółach, tj. wzajemny układ ulic i placów, szerokość i elewacja ulic oraz ich profil zasadniczy [...]". Zauważono również potrzebę wprowadzania zmian w strukturze miasta zabytkowego, ale z zastrzeżeniem, iż ,[...] należy z góry przyjąć założenie, że wszystkie zmiany

${ }^{11}$ Ochronę wartości przestrzennych w układach miejskich uwzględniono w art. 2 , pkt. 5 i 6 Rozporzadzenia Prezydenta Rzeczypospolitej z dnia 6 marca 1928 roku o opiece nad zabytkami (Dz.U., nr 29, poz. 265) oraz w art. 20, 341 i 410 pkt 2 Rozporzadzenia Prezydenta Rzeczypospolitej z dnia 16 lutego 1928 roku o prawie budowlanym i zabudowaniu osiedli (Dz.U., nr 23, poz. 202), a także w art. 337 i 338 zmiany z dnia 14 lipca 1936 roku (Dz.U., nr 56, poz. 405).

${ }^{12}$ Okólnik Ministerstwa Wyznań Religijnych i Oświecenia Publicznego nr 113 z dnia 24 października 1936 roku o ochronie charakteru miast starych i dzielnic staromiejskich, „Biuletyn Urbanistyczny”, marzec 1937 r., R. V, nr 1, ZMP i TUP, Warszawa 1937: 35-37. 
i innowacje takie powinny być stosowane w dawkach jak najmniejszych i tylko w razie koniecznej i istotnej potrzeby".

Okólnik zawierał skierowany do służb wojewody nakaz sporządzenia wykazu miast posiadających dzielnice lub też inne fragmenty (np. place), które były uznane albo mogłyby być uznane za zabytkowe. Ponadto na służby konserwatorskie nałożono obowiązek wydania orzeczeń uznających wskazane miasta lub ich fragmenty za zabytkowe, ,z wyraźnym zaznaczeniem, że orzeczenia takie nie przesądzają jeszcze uznania za zabytki poszczególnych budynków i innych obiektów" (pkt 3). Działania ochronne miały swoje przełożenie również w procesie budowlanym.

Okólnik wskazywał potrzebę sporządzenia przez władze miasta „planów zabudowania zarejestrowanych miast lub dzielnic staromiejskich” (pkt 5), czyli inwentaryzacji zasobu istniejącego oraz docelowo opracowania dla nich ,przepisów miejscowych o budowie poszczególnych zewnętrznych elementów budynków (elewacji) i urządzeń związanych z budynkami, mogących wpłynąć na ich zewnętrzny wygląd” (pkt 6), a także przepisów ustalających zakaz wznoszenia przy ulicach i placach o historycznym lub artystycznym znaczeniu takich budynków, które by mogły zmienić odrębny charakter miejscowości, ulicy lub placu (pkt 6).

Przykładem takich przepisów budowlanych było Zarządzenie Ministra Spraw Wewnętrznych z 1935 roku o budowie poszczególnych elementów elewacji budynków i urządzeń, związanych z budynkami, wpływających na ich zewnętrzny wygląd, opracowane dla miasta Poznania ${ }^{13}$. Określało ono szczegółowe zasady kształtowania elewacji budynków (nazywanych licami frontowymi), dachów, bocznych ścian budowli, ich kolorystyki, lokalizacji bram oraz sposobu umieszczania otworów drzwiowych i okiennych, balkonów i wykuszy, a także regulacji przebiegu i wysokości gzymsów i okapów. Zarządzenie ustalało ponadto sposób lokalizacji budynków w dzielnicach historycznych, ,zwarto zabudowanych", na obszarach których należało nowe inwestycje pod względem „gzymsów, cokołów i otworów okiennych dostosować do sąsiednich budynków istniejących”, aby ,[...] nie powodowały zeszpecenia wyglądu ulicy lub placu" (pkt 6). Przepisy te stanowiły prawo miejscowe, które obowiązywało lokalne władze przy wydawaniu pozwoleń na „budowę, przebudowę lub zmianę budynków" (Okólnik, pkt 8).

${ }^{13}$ Poznański Dziennik Wojewódzki nr 33, poz. 514 z 1935 roku, Zarządzenie Ministra Spraw Wewnętrznych z dnia 16 lipca 1935 roku w sprawie przepisów miejscowych dla miasta Poznania o budowie poszczególnych elementów elewacji budynków i urządzeń, związanych z budynkami, wpływających na ich zewnętrzny wygląd, opracowane na wniosek Wojewody Poznańskiego z dnia 9 kwietnia 1935 roku, Nr KB.I 19/3/34, oparte na uchwale Rady Miejskiej w Poznaniu z dnia 7 listopada 1934 roku. 


\section{Międzywojenne podstawy ksztaltowania miast}

Działania, których celem była ochrona miast historycznych należało uzbroić w wiedzę o ich rozwoju terytorialnym oraz o badania istniejącego zasobu przestrzennego. Konieczność sporządzenia inwentaryzacji zespołów zabytkowych uwzględniło również ustawodawstwo. Dekret Rady Regencyjnej o opiece nad zabytkami sztuki i kultury z 1918 roku wprowadził inwentarz zabytków, który miał określać zabytki podlegające opiece prawa. Stwierdzono, że „,...] prowadzony będzie inwentarz zabytków sztuki i kultury znajdujących się w granicach Państwa Polskiego" (art. 5), a ponieważ ten sam Dekret jako zabytek traktował również „na gruncie dochowane do dziś rozplanowanie starych miast i dzielnic staromiejskich wraz z dawnymi, historycznymi nazwami ulic i placów" (art. 12, ust. f), to akcja inwentaryzacji zabytków w okresie międzywojennym objęła także układy miejskie. Pionierskie badania w tym zakresie prowadzono na Politechnice Lwowskiej, gdzie wykonywanie planów urbanistycznych poprzedzano analizą historycznej struktury urbanistycznej, wykonywaną często w formie zdjęć fotograficznych. Istotne były zdjęcia fragmentów zabudowy dzielnic staromiejskich, całych miast oglądanych z lotu ptaka oraz panoramy ${ }^{14}$ (Lewicki 1999). Ośrodkiem odgrywającym nadrzędną rolę w opracowywaniu dokumentacji inwentaryzacyjnych miast był Zakład Architektury Polskiej, a potem Zakład Budowy Miast na Politechnice Warszawskiej, który gromadził w swoich zasobach zbiory uproszczonych, studenckich planów, przezroczy, fotografii miast oraz wiele rycin i widoków osad historycznych.

Problematyka ochrony krajobrazów miejskich wybrzmiewała także w organizowanych w dwudziestoleciu międzywojennym konkursach urbanistycznych. Rozwijała się potrzeba myślenia o wartościach kulturowych w skali opracowań planistycznych. Warunki konkursów postulowały podjęcie szerokich studiów dotyczących rozwoju przestrzennego badanych miast i miasteczek oraz wprowadzały myślenie o zabytkach w skali odbioru krajobrazu kulturowego. Zaczęła materializować się idea teoretyków, którzy dążyli do wprowadzenia wiedzy historycznej $\mathrm{w}$ praktyczne działania urbanistów poprzez tzw. studia wstępne do planów zabudowania (Kłosek-Kozłowska 2007). Ich celem była dokładna kwerenda rozwoju jednostek miejskich, a w szczególności pozyskanie wiedzy z zakresu nawarstwień zabudowy, zmian w układach drogowych, reparcelacji wtórnej działek gruntu oraz uwarunkowań regionalnych. Przykładem takich „,studiów wstępnych" były prace wykonane w 1935 roku przez Biuro Pomiarów i Planów Zabudowania przy Wydziale Wojewódzkim Wołyńskim, jako podstawa do sporządzania programu planu miasta Równego i ogłoszenia konkursu powszech-

${ }^{14}$ Niestety, lwowskie zasoby inwentaryzacyjne (z wyjątkiem ocalonych zasobów fotograficznych) nie ocalały. We wrześniu 1939 roku, po zajęciu Lwowa przez wojska ZSRR, zbiory spalono na dziedzińcu głównego budynku politechniki, uznając je za materiał wywiadowczy. 
nego na projekt szkicowy planu zabudowania ${ }^{15}$. Były one wskazywane jako nowoczesne podejście metodologiczne, zawierające szczególne wartości analityczne i waloryzacyjne z zakresu przestrzeni miasta i jego historii.

Coraz częściej temat kształtowania krajobrazów miejskich występował w dyskusjach i polemikach środowiska urbanistów. Nowelizacja przepisów budowlanych z 1936 roku $^{16}$ wprowadzała obowiązek sporządzania planów zabudowania, które miały na celu przeprowadzanie regulacji i prawidłowego kształtowania miast i miasteczek oraz uzdrowisk posiadających funkcję użyteczności publicznej. Dla innych obszarów plany zabudowania można było sporządzać fakultatywnie. Najczęściej przygotowywano je w oparciu o zdjęcia sytuacyjne i wysokościowe w skali ogólnej lub szczegółowej.

Plany ogólne należało sporządzać dla obszaru całego miasta lub znacznej jego części albo dla kilku sąsiadujących osiedli, natomiast plany szczegółowe - na podstawie prawomocnego, opracowanego wcześniej planu ogólnego, obejmującego obszar całego osiedla lub jego fragmentów. W skali ogólnej wyznaczano linie regulacyjne ograniczające obszary przeznaczone na główne arterie komunikacyjne, budynki, zakłady i urządzenia użyteczności publicznej, place miejskie, skwery, parki, ogrody i inne podobne urządzenia przeznaczone do użytku społecznego. Konstruując ustalenia planu, wprowadzono podział miejscowości na strefy według sposobu zabudowania, który klasyfikowano jako ,[...] jednolub wielopiętrowy, zwarty, grupowy, luźny lub mieszany, ogniotrwały lub nieogniotrwały, gdy taki był dopuszczalny" (art. 10, pkt 2). W skali całego miasta wyznaczono również strefy funkcjonalne, w szczególności przeznaczone na cele mieszkaniowe oraz mieszkaniowe z dopuszczeniem zakładów przemysłowych niezagrażających bezpieczeństwu, życiu i zdrowiu ludzi (art. 18). Dla nich należało przeznaczać odrębne dzielnice. Czasami jednak, zamiast ogólnego planu zabudowania, praktyczniej było sporządzić plan szczegółowy, który opierał się na programie ogólnego rozwoju miasta.

W planie szczegółowym zabudowania wyznaczono linie regulacyjne z dokładnym przebiegiem arterii komunikacyjnych razem z urządzeniami pomocniczymi, frontowe linie zabudowy, poziom ulic i placów oraz sposób zabudowania gruntów budowlanych, a szczególnie tylne linie zabudowy, których nie można było przekraczać tylnymi ścianami domów wznoszonych przy ulicach lub w głębi działek budowlanych. Przyjęta nowelizacja przepisów budowlanych wprowadzała

${ }^{15}$ Studia wstępne dla miasta Równego opublikowano w 1936 roku w „Biuletynie Urbanistycznym”, opracowywanym przez Towarzystwo Urbanistów Polskich jako dodatek do publikacji „Samorząd Miejski”, wydawany przez Związek Miast Polskich. BU, Warszawa, kwiecień 1936, R. IV, nr 1: 24-43.

${ }^{16}$ Rozporzadzenie Prezydenta Rzeczypospolitej z dnia 16 lutego 1928 roku o prawie budowlanym i zabudowie osiedli (Dz.U., nr 23, poz. 202), zmienione nowelizacją z dnia 14 lipca 1936 roku (Dz.U., nr 56, poz. 405). 
również zasady lokalizacji zabudowy zarówno przy nowo zakładanych, jak i istniejących publicznych ulicach.

W jeszcze bardziej szczegółowych przepisach miejscowych można było wprowadzić zakaz wznoszenia budynków mieszkalnych przy ulicach nieurządzonych (art. 410, pkt 1), wymiary działek budowlanych (art. 408, pkt 2) oraz minimalne dopuszczalne rozmiary niezabudowanej przestrzeni na poszczególnych działkach budowlanych (art. 408, pkt 3). Ponadto w przepisach określano sposób zabudowania działek z uwzględnieniem rodzaju zabudowy, a także odległość budynków od bocznych granic działki, ulic i dróg oraz innych naniesień budowlanych. Przepisy pozwalały również kształtować formę dachów i ogrodzeń. Można było wprowadzić dopuszczalny kąt nachylenia dachów w stosunku do poziomu terenu, sposób przykrycia budynków oraz inne warunki, jakim musiały odpowiadać konstrukcje i wygląd zewnętrzny zabudowy (art. 408). Lica budynków i wszelkie powierzchnie murów, widoczne z jakichkolwiek dróg komunikacji publicznej ,powinny być tak wykonane, iżby nie powodowały zeszpecenia placu, ulicy albo podwórza" (art. 262). Ponieważ przepis odnosił się do wszelkich dróg komunikacji publicznej przyjmowano, że dotyczył on płaszczyzn murów widocznych nie tylko z ulic i placów, lecz także innych dróg komunikacyjnych, takich jak koleje żelazne lub drogi wodne (Szymkiewicz 1938: 313).

Realizowane budynki nie mogły spowodować zeszpecenia ulicy, placu lub podwórza, zarówno ze względu na niewłaściwy sposób ich wykonania (stosunek poszczególnych elementów elewacji, rodzajów materiałów), jak i niedostosowanie do otoczenia, czyli do formy i elewacji sąsiednich budynków. Lokalizowanie frontów budynków pod kątem ostrym do linii ulicy lub placu można było traktować jako niedostosowanie ich do otoczenia, do którego należały nie tylko sąsiednie budynki, ale również ulica publiczna (art. 408, pkt 6 i 7). Przepisy miejscowe ustalały też podstawy do wydawania szczegółowych regulacji kształtujących zewnętrzny wygląd budynków. Wydanie takich przepisów było istotne zarówno dla ochrony istniejącej substancji miasta, jak i nowej zabudowy, ponieważ ustalały postępowanie pod względem wielu trudności i wątpliwości, które napotykały w tamtych czasach władze i interesanci, gdy chodziło o ocenę budynków z punktu widzenia estetycznego. Przepisy miejscowe odnosić się mogły również do kolorystyki budynków. Artykuł 263 (ust. 1) zabraniał malowania elewacji w kolorach jaskrawych lub rażących, o ile same przepisy miejscowe nie określały, jakie kolory należy za takie uznać. Ocena tego w każdym konkretnym wypadku należała do władzy udzielającej pozwolenia na budowę.

Plany szczegółowe zabudowania określać można było dla miast i uzdrowisk posiadających charakter użyteczności publicznej oraz dla fragmentów przestrzeni miejskich nazywanych osiedlami. Prawo budowlane z 1928 roku (art. 6) określało pojęcie osiedla, które rozumiane było jako fragment miasta, miasteczka lub uzdrowiska, osady wiejskiej i fabrycznej, kolonii robotniczej, a nawet skupiska zabudowy obejmującego w jednej grupie co najmniej 10 budynków mieszkal- 
nych. Szczególną formą osiedla mogła być dzielnica śródmiejska lub jej fragment posiadające walory historyczne. Musiał być jedynie spełniony warunek skupienia co najmniej 10 budynków, ale tylko wówczas, gdy skupienie takich budynków ze względu na bliskie wzajemne położenie stanowiło pewną odrębną całość, wyraźnie oddzieloną od innych zespołów budynków (Bodek 1935).

Fakt, że z mocy prawa plany w formie szczegółowej można było wykonywać również dla staromiejskich dzielnic w mieście, intensyfikował próby urbanistów i konserwatorów międzywojennych do wprowadzenia do prawodawstwa polskiego praktyki szczegółowych planów zabudowania dla obszarów zabytkowych (ryc. 2). Uważano, że powinny one zawierać wszystkie elementy zwykłego planu szczegółowego, ale z uwzględnieniem specjalnych postulatów konserwatorskich. W środowisku urbanistów podjęto próbę wypracowania zakresu takiego planu w ramach prac w Biurze Regulacji miasta Krakowa. Uznano, że plan szczegółowy dotyczący obszarów zabytkowych powinien zawierać przekroje ulic, wysokości projektowanych budynków, liczbę dopuszczalnych kondygnacji, tylną linię zabudowy, nachylenie dachu, rodzaj pokrycia, gabaryty fasad, ale jednocześnie zagadnienia szczególne związane z kompozycją i rozwojem zabudowy historycznej. Wśród najważniejszych wymieniano: ogólną kompozycję fasad, rozmieszczenie akcentów architektonicznych, rodzaj oświetlenia, wystawy sklepowe i portale oraz szczególną formę reklam, w tym miejsca ich lokalizacji z wyłączeniem pewnych fragmentów tkanki miejskiej, w której powinny być one zakazane.

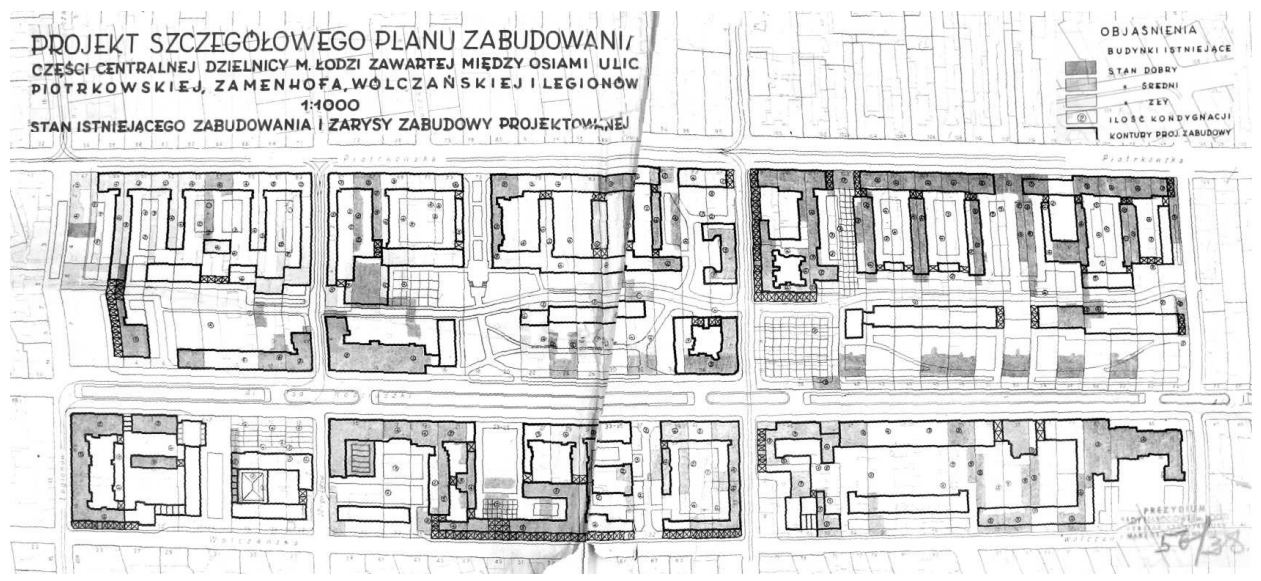

Ryc. 2. Projekt szczegółowego planu zabudowania dla fragmentu centralnej dzielnicy miasta Łodzi. Wyraźnie widać „próbę sił” pomiędzy rozluźnianiem struktury miejskiej

(przewietrzanie podwórek, szersze ulice) a zachowaniem tkanki zabytkowej

(zabudowa oficynowa, podziały własnościowe)

Autor: Magistrat, Wydział Budownictwa, Oddział Zabudowy Miasta, Łódź

Data opracowania: $1938 \mathrm{r}$.

Źródło: Archiwum Państwowe w Łodzi, Zbiory Ikonograficzne (syg. 56/38) 
Szczególną uwagę proponowano zwracać na tzw. momenty widokowe, kształtujące kompozycję miasta. Wskazywano również na odmienne metody pracy przy sporządzaniu planów zabudowania dla dzielnic zabytkowych oraz większą szczegółowość poprzedzających je badań przestrzennych i rozwojowych. W ramach prac nad planami zabudowy dla struktur miejskich wskazywano konieczność opracowania inwentaryzacji zabytków i wykonania studiów historycznych. Rozważania dotyczące szczegółowości i konsekwencje opracowania szczegółowego planu zabudowania dla obszarów zabytkowych dotyczyły także aspektów fiskalnych. W celu ułatwienia realizacji planów wskazywano potrzebę przeprowadzenia odpowiedniej nowelizacji ustawy podatkowej w kierunku ulg finansowych dla budynków uznanych za zabytkowe. Stwierdzono, że „nie ulega wątpliwości, iż budynki takie, jako mniej rentowne a wymagające specjalnej i kosztownej konserwacji, powinny być łagodniej traktowane w stosunku do reszty budynków" (Śmigielski 1936: 29) ${ }^{17}$.

Okres międzywojenny to czas projektowania urbanistycznych systemów ochrony dawnych miast. Pierwsze polskie próby konstruowania zasad prawa odnoszącego się do obszarowego myślenia o historycznych wartościach miejskich zostały brutalnie przerwane w 1939 roku, ale należy uznać je za istotną podwalinę powojennych działań planistycznych i konserwatorskich. Ich znaczenie podkreśla fakt, że odbywały się w czasach nowoczesnej awangardy kulturowej i dominującej doktryny modernistycznej.

\section{Powojenne badania wartości zasobów przestrzennych}

Po drugiej wojnie światowej, aż do 1962 roku, w zakresie ustawodawstwa fundamentem ochrony zabytków pozostawało przedwojenne Rozporządzenie Prezydenta z mocą ustawy o opiece nad zabytkami z $1928 \mathrm{roku}^{18}$. Pomimo braku nowych podstaw prawnych oraz sytuacji politycznej w powojennej Polsce, realizowano wiele działań, których celem było zachowanie historycznych zespołów miejskich.

${ }^{17}$ Prace nad planem zabudowy dla strefy zabytkowej miasta Krakowa na tle pomiarów konserwatorskich wykonane w Biurze Regulacji Miasta Krakowa opisał Władysław Śmigielski. Szczegółowość planów w strefie śródmiejskiej autor odniósł do zasad finansowania działań konserwatorskich.

${ }^{18}$ „Należy jednak zauważyć, że praktyczna ochrona zabytków w Polsce Ludowej, mimo że nadal oparta na podstawie prawa z 1928 roku, w procesie realizacyjnym nie czerpała wprost z przedwojennych wzorów i zasad. Przede wszystkim, wskutek zmiany poglądów na państwo i prawo, zmieniło się pojmowanie zabytku, a podejście do zabytków nasyconych regionalizmem i charakterem miejsca było często traktowane w ramach «szlachetczyzny i klerykalizmu», co miało wpływ na ich odbudowę i adaptację oraz działania przestrzenne w skali urbanistycznej”- pisał B. Rymaszewski (1984: 140). 
Początkowo podejmowano próby tworzenia skróconych zbiorów danych ewidencyjnych, gromadzono zbiory materiałów do badań naukowych dotyczących miast historycznych, zbierano przerysy, reprodukcje planów historycznych oraz zdjęcia lotnicze. W 1961 roku, na zlecenie Zarządu Muzeów i Ochrony Zabytków, opracowano zasady ogólnokrajowej inwentaryzacji miast zabytkowych. Zespół w składzie: J. Łosowski, M. Przyłęcki i M. Witwicki przygotował zasady wykonywania kartotek. Nowy schemat ewidencji przedstawiono do dyskusji na naradzie w Zarządzie Muzeów i Ochrony Zabytków. Projekt zespołu, merytorycznie oceniony bardzo pozytywnie, uznano jednak za zbyt szczegółowy i kosztowny w realizacji. W rezultacie oparta na nim instrukcja ewidencyjna wprowadziła mniejszy zakres dostosowany do indywidualnych możliwości finansowych samorządów. Jak opisywała to instrukcja, założeniem ewidencji miast zabytkowych było „stworzenie krótkiego zestawu danych, które miały służyć ogólnej orientacji w dziejach miasta i stanie zachowania elementów zabytkowego układu przestrzennego" (Witwicki 1966: 33-38).

Materiał gromadzony był w formie sformalizowanych tek urbanistycznych dla poszczególnych miast. Należy podkreślić skuteczność działań przy opracowywaniu wskazanej dokumentacji. Do 1964 roku wykonano 1246 tek urbanistycznych dla miast i 24 dla wsi. Uzyskano wartościowy materiał do dalszej pracy konserwatorów i planistów, zawierający zbiór materiałów bibliograficznych, kartograficznych, graficznych i tekstowych.

Odbudowa układów osadniczych, zniszczonych w wyniku drugiej wojny światowej, wywołała konieczność ścisłej współpracy pomiędzy środowiskiem urbanistów i konserwatorów oraz potrzebę szukania metod ochrony wartości historycznych w skali całych układów osadniczych. Ochronę miast zabytkowych trafnie zdefiniował Jan Zachwatowicz: „Do kształtowania nowych wartości kulturalnych niezbędna jest ciągłość, oparta o świadomy stosunek do przeszłości, o ewolucję form życia, myślenia i odczuwania właściwego pokoleniom, które stworzyły naród i jego historię. Dlatego należy przyjąć takie zasady, aby tę przeszłość, objawioną w zabytkach włączyć do życia w każdej skali" (Zachwatowicz 1946).

Już w 1946 roku Jan Zachwatowicz rozpoczął formułowanie programu i zasad konserwacji zabytków, w tym układów urbanistycznych. Na łamach „Biuletynu Historii Sztuki i Kultury" przedstawił kierunki niezbędne przy odbudowie miast polskich. Twierdził, że ,istotnym elementem krajobrazu i jego sugestywnym akcentem jest osiedle, a stworzenie dla niego jasnej koncepcji urbanistycznej ułatwi sprecyzowanie programu również dla zachowania w nim elementów zabytkowych"19.

${ }^{19}$ Zasady i program konserwacji zabytków Jana Zachwatowicza był zagadnieniem poruszanym na naradzie w Nieborowie w dniach 30 września-1 października 1950 roku. Wymagania Ochrony Zabytków Urbanistycznych wobec nauki historycznej opisano w pracach Instytutu Urbanistyki i Architektury (IUA) z 1952 roku. 
Autor podkreślał rolę planowania przestrzennego oraz wartość analiz obszarowych w procesie odbudowy i kształtowania rozwoju przestrzennego miast.

Dyskusje o formach obszarowej ochrony zabytkowych miast podjęto w latach 50. XX wieku na I Ogólnopolskim Zjeździe Konserwatorskim w Krakowie $^{20}$ (Manganowa 1952). Stwierdzono, że w związku z szybko postępującą odbudową i przebudową miast i osiedli, posiadających wiele elementów zabytkowych godnych zachowania i włączenia do życia współczesnego, należy rozszerzyć prace $\mathrm{w}$ zakresie przygotowywania dokumentacji konserwatorskich i nawiązać współpracę z odpowiednimi zakładami uniwersyteckimi i politechnicznymi. W dyskusji wskazywano potrzebę podjęcia akcji stworzenia jednolitej, rozszerzonej dokumentacji historyczno-konserwatorskiej, jako podstawy do sporządzania planów urbanistycznych oraz włączenie takich dokumentacji do kosztorysu sporządzania planów zagospodarowania miast. Nieformalnie badania zasobów kulturowych stały się częścią dokumentacji planistycznych.

W działaniach obszarowych $\mathrm{w}$ mieście zaczęto używać pojęcia rewaloryzacji zespołu staromiejskiego. Oznaczała ona całokształt działań w dziedzinie gospodarki przestrzennej, które podporządkowane były celowi przywrócenia i utrwalenia historycznie ukształtowanych elementów istniejących w zespole staromiejskim. Rewaloryzacja oznaczała kierunek wszelkich działań gospodarczych podejmowanych na określonym obszarze $\mathrm{w}$ procesie rozwojowym miasta oraz na różnorodnych poczynaniach budowlanych, od prac konserwatorskich, przez prace modernizacyjne i remontowe, aż po wymianę bezwartościowych kulturowo i technicznie budynków na nowe, a w pewnych wypadkach wprowadzała również budowę tzw. plomb. Oczywiście realizując nowe kubatury, z założenia należało przestrzegać ścisłej dyscypliny przestrzennej i architektonicznej zgodnie z wytycznymi konserwatorskimi. Życie jednak pisało własne scenariusze, co w niektórych układach miejskich jest przestrzennie widoczne do dzisiaj w formie odmiennych, modernistycznych założeń urbanistycznych i realizacji architektonicznych. Podstawowymi dokumentami dla prowadzenia działań rewitalizacyjnych na obszarze miasta były oczywiście plany zagospodarowania przestrzennego. Tryb i zakres opracowania tych dokumentów był określony aktami normatywnymi i wytycznymi Ministerstwa Administracji, Gospodarki Terenowej i Ochrony Środowiska. W planach należało określać warunki ochrony i rewaloryzacji historycznych zespołów urbanistycznych. Problematyka rewitalizacyjna zaistniała we wszystkich skalach opracowań planistycznych - od regionalnej w planach zagospodarowania przestrzennego województw, poprzez lokalną w planach zagospodarowania przestrzennego gmin, aż do detalicznych ustaleń w planach szczegółowych ${ }^{21}$.

${ }^{20}$ I Ogólnopolski Zjazd Konserwatorski w Krakowie odbył się w dniach 28 września -2 października 1952 roku.

${ }^{21}$ Do 1961 roku studia historyczno-urbanistyczne ograniczone były do skali planu ogólnego. Obowiązek ich opracowywania w różnych skalach planistycznych wprowadzono 
Opracowaniem klasyfikacji historycznych zespołów miejskich zajął się Ośrodek Dokumentacji Zabytków w Warszawie, powierzając przygotowanie zasad i wytycznych klasyfikacji przedstawicielom Politechniki Warszawskiej (Instytutu Podstawowych Problemów Planowania Przestrzennego oraz Instytutu Badań Zasobu Mieszkaniowego) pod kierunkiem Krzysztofa Pawłowskiego i Michała Witwickiego. Dokument będący wynikiem pracy zespołu ustalał metodę obiektywnej oceny układów urbanistycznych. Autorzy do oceny wartości zabytkowych miast ułożyli system kryteriów podstawowych i pomocniczych, posiłkując się wartościami relatywnymi o szerokiej skali porównawczej. Do kryteriów podstawowych zaliczono te, które odnosiły się do stanu zachowania dawnego układu przestrzennego, w szczególności wzięto pod uwagę rozplanowanie zasadniczych elementów struktury miasta, takich jak: główne place, ciągi komunikacyjne, osie kompozycyjne, budynki oraz elementy dawnego programu miejskiego, głównie obiekty użyteczności publicznej, dzieła inżynierskie i inne. Za kryteria pomocnicze uznano natomiast te, przy stosowaniu których dużą rolę odgrywał odbiór subiektywny. Były to kryteria wartości estetycznej oraz kryteria bogactwa tradycji historycznej w skali regionu i miasta. Metoda miała formę karty klasyfikacyjnej, w której przyjęto system punktowy, zakładający skalę od jeden do pięciu punktów, zróżnicowaną w zależności od stopnia szczegółowości, w jakim rozpatrywano zespół urbanistyczny (Pawłowski, Witwicki 1973). Suma punktów była wynikiem ogólnej klasyfikacji, która decydowała o kategorii wartości zabytkowej analizowanego zespołu miejskiego. Zaproponowane kryteria oceny poddano dyskusji na konferencji konserwatorsko-urbanistycznej, która odbyła się 22 listopada 1967 roku w Warszawie (Andrulewicz 1968).

System kryteriów wartościujących wykorzystano w publikacji Miejskie Zespoły Zabytkowe w Polsce, przygotowanej po 1968 roku z inicjatywy Zarządu Muzeów i Ochrony Zabytków Ministerstwa Kultury i Sztuki, a następnie Ośrodka Dokumentacji Zabytków. Dla miast przedstawionych w opracowaniu sporządzono zarys rozwoju przestrzennego, omówiono stan istniejący, sformułowano wnioski konserwatorskie i podano najważniejsze dane bibliograficzne. Istotna była również część ilustracyjna, która zawierała aktualny ówczesny plan pomiarowy sekcji historycznych miasta $\mathrm{w}$ skalach 1:5000 i 1:2000, z wyznaczeniem proponowanych stref konserwatorskich oraz zdjęcia lotnicze układów miejskich. Opracowanie powierzono specjalistom z zakresu dziejów i budowy miast, znawcom zagadnień urbanistyki, zabytków i problemów konserwatorskich, urbanistom i architektom z całego kraju, w szczególności z różnych ośrodków akademickich oraz służbom ośrodka dokumentacji zabytków (Maliszewski, Andrulewicz, Łotysz 1971).

w Zarządzaniu Wykonawczym nr 47 z 29 lipca 1961 roku w sprawie szczegółowych przepisów o sporządzaniu miejscowych planów zagospodarowania przestrzennego. Wprowadzono wtedy również hierarchię planów z podziałem na poziom: krajowy, wojewódzki, ogólny i szczegółowy (Ustawia z dnia 31 stycznia 1961 roku o planowaniu przestrzennym). 
Istota kształtowania miast zabytkowych doprowadziła do podjęcia przez Radę Ministrów Uchwały nr 101 z 21 lipca 1978 roku w sprawie powołania Międzyresortowej Komisji do spraw Rewaloryzacji Miast i Zespołów Staromiejskich. W skład komisji wchodzili przedstawiciele resortów ministerialnych uczestniczących w procesie rewaloryzacji, a ciałem merytorycznym był Zespół Ekspertów do spraw Rewaloryzacji Miast i Zespołów Staromiejskich. W oparciu o dostępne materiały zespół ekspertów dokonał wszechstronnych analiz 1363 miejscowości, które w historycznym rozwoju uzyskały lokacje i prawa miejskie. Spośród nich 802 miejscowości, w tym 600 miast i 202 wsie, zachowały w różnym stopniu historyczne układy urbanistyczne wymagające ochrony. Inna analiza wykazała, że zachowane zespoły staromiejskiej zabudowy zabytkowej w 164 miejscowościach wymagały specjalistycznego opracowania konserwatorskiego, a w 282 znajdowała się zabudowa dziewiętnastowieczna i późniejsza o szczególnych cechach architektonicznych. Spośród tych dwóch grup 205 miejscowości miało wyjątkowe wartości krajobrazowo-przestrzenne zespołu staromiejskiego. Poza wspomnianymi dwiema grupami w 397 miejscowościach zachowały się historyczne założenia urbanistyczne w planie układu zabudowy miasta (Maliszewski, Andrulewicz, Łotysz 1971: 234).

\section{Studia rozwoju osadnictwa, studia historyczno-urbanistyczne i strefy ochrony obszarowej}

W 1981 roku Zespół Ekspertów Międzynarodowej Komisji do spraw Rewaloryzacji Miast i Zespołów Staromiejskich opracował „Wytyczne do opracowania problematyki ochrony wartości kulturowych w planach zagospodarowania przestrzennego"22. Materiał ten należało traktować jako podstawę do stosowania przy określaniu ustaleń konserwatorskich w opracowaniach planistycznych dla obszarów zabytkowych (ryc. 3). Co ciekawe, w dużej mierze wytyczne owe są stosowane również we współczesnych dokumentach planów miejscowych w formie stref obszarowych (ryc. 8), mimo że nie mają wprost umocowania w przepisach prawa z zakresu ochrony zabytków czy kształtowania przestrzeni.

Wytyczne stosowano przy opracowywaniu dokumentacji, które miały charakter zbioru informacji i wskazań konserwatorskich do dokumentów planistycznych. Nazywano je studiami historyczno-urbanistycznymi lub konserwatorsko-urbanistycznymi. Ich zakres z założenia był dostosowany do problematyki i zadań skali danego planu. Miały one charakter informacyjny, ale wypracowane

${ }^{22}$ „Wytyczne do opracowania problematyki ochrony wartości kulturowych w planach zagospodarowania przestrzennego", opracowane przez Zespół Ekspertów Międzyresortowej Komisji ds. Rewaloryzacji Miast Zespołów Staromiejskich, stanowiły załącznik do pisma Ministerstwa Kultury i Sztuki oraz Ministerstwa Administracji, Gospodarki Terenowej i Ochrony Środowiska z dnia 27 listopada 1981 roku, Warszawa 1981. 
w nich wytyczne konserwatorskie były składową formalno-prawnej części planu zagospodarowania przestrzennego. Wytyczne określały zasób koniecznych danych do ochrony wartości kulturowych i rewaloryzacji historycznych układów przestrzennych oraz wskazywały zakres merytoryczny, jaki należało uwzględnić przy opracowywaniu planu województwa, ogólnego planu zagospodarowania miasta oraz szczegółowego planu zagospodarowania przestrzennego i rewaloryzacji.
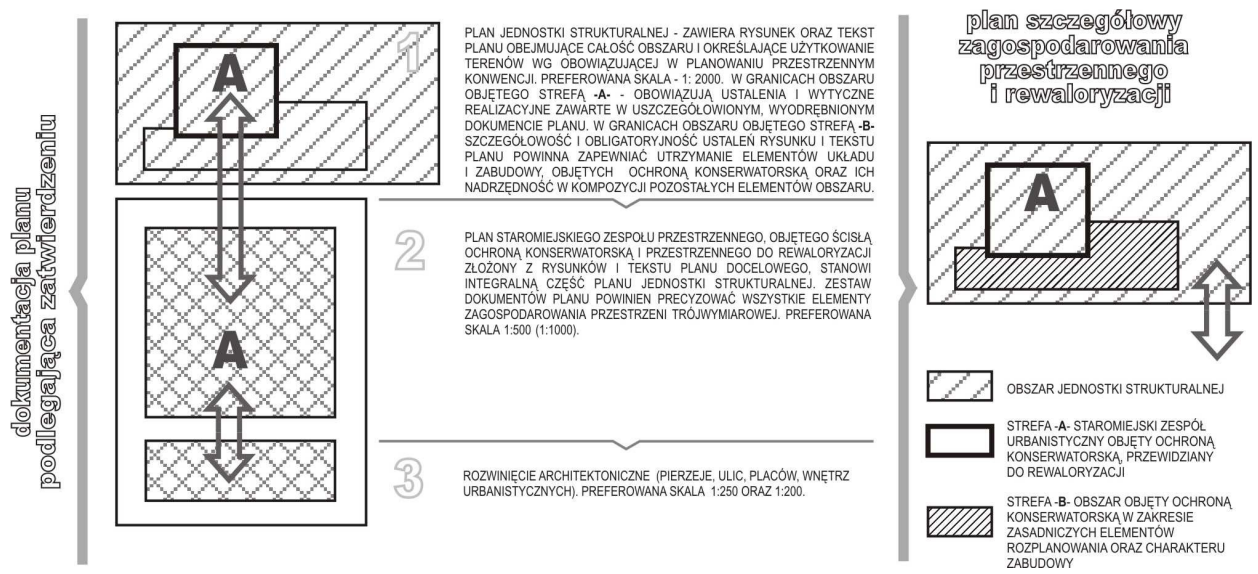

Ryc. 3. Schemat jednostki strukturalnej objętej szczegółowym planem zagospodarowania przestrzennego i rewaloryzacji (A); schemat konstrukcji dokumentacji planu (B)

Źródło: „Wytyczne do opracowania problematyki ochrony wartości

kulturowych w planach zagospodarowania przestrzennego" (1981: 23)

Skala i problematyka planu zagospodarowania przestrzennego województwa pozwalała jedynie na określenie zadań globalnych ${ }^{23}$. Wytyczne wskazywały na etapie zbierania materiałów do planu konieczność opracowania studium historycznego rozwoju osadnictwa, a w nim m.in. określenia terenów, zespołów budynków i obiektów o wartościach kulturowych, ich stanu technicznego i własnościowego oraz sposobu użytkowania. W ramach analiz należało zdiagnozować czynniki zagrożeń dla wartości kulturowych, takie jak: funkcjonujący przemysł, oddziaływanie komunikacyjne, spiętrzanie wód czy energetyczne linie przesyłowe. Zatwierdzony dokument planu zagospodarowania przestrzennego województwa musiał zawierać następujące ustalenia:

- wykaz miejscowości zawierających zachowane historyczne staromiejskie układy przestrzenne przewidziane do rewaloryzacji oraz określenie ich funkcji w strukturze przestrzennej województwa,

${ }^{23}$ Wytyczne stanowiły uzupełnienie zasad określonych przez Ministerstwo Administracji, Gospodarki Terenowej i Ochrony Środowiska z czerwca 1976 roku oraz materiałów opracowanych przez Instytut Kształtowania Środowiska z września 1976 roku dotyczących trybu i metody opracowania planu województwa. 
- kierunki i charakter działań rewaloryzacyjnych w odniesieniu do wyżej wymienionych miejscowości oraz wnioski do ich realizacji,

- wykaz wsi podlegających ochronie konserwatorskiej oraz ustalenie warunków ich ochrony,

- ustalenie obowiązku opracowania planów szczegółowych i rewaloryzacji dla zespołów staromiejskich oraz planów szczegółowych dla wsi o historycznych układach przestrzennych,

- informacje i wnioski dla planowania społeczno-gospodarczego, zawierające zadania priorytetowe i etapowanie procesów rewaloryzacji, wstępny szacunek wielkości nakładów na realizację wskazanych działań oraz wnioski dotyczące zapewnienia warunków realizacji.

W planie województwa musiały być również sformułowane wnioski do planu krajowego, w tym określenie globalnych zadań w zakresie rewaloryzacji oraz wykaz zespołów staromiejskich podlegających ochronie o znaczeniu ponadlokalnym.

W skali miasta podstawowym opracowaniem było studium historyczno-urbanistyczne (Zarębska 1973). Opracowywano je dla potrzeb planu ogólnego miasta oraz planu szczegółowego zespołu staromiejskiego. Musiało ono wyczerpywać zakres zagadnień konserwatorskich występujących w obszarze planu w stopniu dokładności pozwalającym na sformułowanie wytycznych do planu szczegółowego. Taka konstrukcja studium umożliwiała optymalną syntezę wniosków również dla małych miejscowości, dla których faza planu ogólnego mogła być pomijana. Studium musiało składać się z trzech podstawowych elementów: zbioru materiałów dotyczących stanu istniejącego miasta, oceny i charakterystyki tych materiałów oraz wytycznych i postulatów konserwatorskich. Do najważniejszych materiałów wyjściowych zaliczano:

- badanie stanu istniejącego oraz ocenę wartości zabytkowej historycznego układu urbanistycznego i jego funkcji w organizmie miejskim,

- główne elementy kompozycji, podstawowe ciągi komunikacyjne, obiekty i zespoły organizujące sylwetę i główne wnętrza układu urbanistycznego,

- wykaz i ocenę obiektów i elementów terenowych o wartościach kulturowych, takich jak obiekty zabytkowe objęte rejestrem i ewidencją konserwatorską oraz obiekty zasługujące na ochronę ze względu na szczególne walory kulturowe. Dotyczyło to nie tylko budynków, ale również urządzeń obronnych i inżynieryjnych, założeń parkowych, ulic, placów oraz stanowisk archeologicznych.

Istotna była przy tym szczegółowa analiza problematyki przestrzennej układu zabytkowego. W ramach badań należało wskazać:

- podstawowe elementy ewolucji układu przestrzennego wraz z rozwarstwieniem chronologicznym jego komponentów,

- aktualną sytuację i funkcję ośrodka historycznego w strukturze przestrzennej jednostki osadniczej w powiązaniu z terenami otaczającymi, 
- strukturę przestrzenną ośrodka historycznego z określeniem stopnia jego jednorodności lub złożoności i ewentualnym wyodrębnieniem jednostek morfologicznych,

- wartości zabytkowe elementów przestrzennych, a w szczególności obiekty i zespoły zabytkowe, historyczne rozplanowanie zabudowy i sieci drogowej, zabytkowe przestrzenie zielone oraz obszary o wartościach archeologicznych. Studia waloryzowały również wartości przestrzenno-krajobrazowe, w tym powiązanie struktur chronionych z obszarem otaczającym, wnętrza o szczególnych wartościach estetycznych i krajobrazowych, ważne punkty i osie widokowe, obiekty dominujące i dysharmonijne w krajobrazie, a w szczególnych przypadkach inżynieryjne elementy układu podziemnego.

Najważniejszym elementem studiów historyczno-urbanistycznych były określane w nich wytyczne i postulaty konserwatorskie. Dotyczyły one zarówno wskazówek w zakresie ochrony i przekształceń pojedynczych obiektów i zespołów zabytkowych, jak i postulatów przestrzennych przyjmowanych w skali urbanistycznej. Ochronę obszarową przyjmowano w formie stref ochrony konserwatorskiej (Pawłowski, Witwicki 1973). Warto podkreślić tutaj rolę wyznaczonych stref, ponieważ sposób ich zapisu przetrwał w dokumentach planistycznych do dziś. W planie miasta można było wyznaczyć pięć stref ochronnych dla różnych elementów tkanki urbanistycznej analizowanej w różnych skalach. Strefa „A”, nazywana strefą pełnej ochrony konserwatorskiej, obejmowała obszar, na którym występowała dobrze zachowana historyczna struktura przestrzenna. Zakładano jej nienaruszalność i jedynie cząstkowe modyfikacje formy, które musiały być podporządkowane historycznej kompozycji przestrzennej. W planie ogólnym w ramach wyznaczanej strefy przyjmowano bezwzględny priorytet ustaleń konserwatorskich i obowiązek opracowania szczegółowego planu zagospodarowania przestrzennego. Strefa „B”, nazywana strefa zachowania układu rozplanowania, obejmowała obszar podlegający ochronie urbanistycznej w zakresie jej zasadniczych elementów planistycznych i budowlanych. Dopuszczano tu możliwość pewnych modyfikacji z zastrzeżeniem zachowania wzajemnej spójności pomiędzy elementami kompozycji historycznej i współczesnej. Strefa „E”, nazywana strefą ekspozycji, obejmowała obszar, którego zadaniem było zabezpieczenie właściwej ekspozycji zabytkowego układu przestrzennego. Najczęściej występowała wokół strefy „A” lub „B”. Podstawowym obowiązkiem w strefie „E” było zachowanie określonych gabarytów zabudowy lub po prostu jej zakaz. Strefa ochrony krajobrazu, określana jako strefa „K”, obejmowała elementy krajobrazu i terenu integralnie powiązanego z zabytkowym układem przestrzennym. Wyznaczano ją także w przypadku, gdy krajobraz stanowił w przeszłości część kompozycji urbanistycznej istotnej dla historycznego charakteru zespołu. W strefie ochrony krajobrazu, szczególnie w tkance miejskiej, często występowała integralnie 
strefa ekspozycji o mniejszym zasięgu i bardziej ukierunkowanym odbiorze przestrzennym. Ostatnia strefa, obejmująca obszary zastrzeżone do badań archeologicznych, nazywana była strefą „W”, czyli strefą ochrony archeologicznej. W ramach jej granic miano wskazywać potencjalne miejsca i dokonywać eksploracji archeologicznej. W planach ogólnych wymienione wyżej strefy ochrony konserwatorskiej mogły się nakładać i uzupełniać.

Szczególną formę przyjmowały zapisy dotyczące ochrony elementów dziedzictwa kulturowego wprowadzone w szczegółowych planach zagospodarowania przestrzennego i rewaloryzacji. Zakres merytoryczny planów obligował do dużej szczegółowości ustaleń tekstowych i graficznych z uwzględnieniem problematyki architektonicznej. Takie plany wykonywano dla stref śródmiejskich i dzielnic centralnych. Skala planów mogła być opracowywana na dwóch poziomach szczegółowości - w przypadku kiedy plan obejmował obszar większy od zespołu staromiejskiego przewidzianego do rewaloryzacji, należało opracować dokumentację planu w skali 1:2000 dla całości, a dla zespołu historycznego 1:1000 lub 1:500.

Na potrzeby planów szczegółowych należało wykonywać studia konserwatorsko-urbanistyczne ${ }^{24}$ (ryc. 4), opracowania fizjograficzne oraz dokładną inwentaryzację urbanistyczną i architektoniczną, obejmującą analizę budynków, zieleni, własności i uzbrojenia. Opracowania te traktowano jako zadania dodatkowe, niewchodzące w skład samego planu.

Szczegółowa problematyka przyjmowana w ustaleniach planów szczegółowych i planów rewitalizacji była ustalana indywidualnie dla każdego terenu i w zależności od jego specyfiki ograniczana, agregowana lub uzupełniana dodatkowymi elementami. Badania, oprócz typowych elementów związanych z dziedzictwem kulturowym, takich jak analiza stanu własności na tle przekształceń historycznych oraz wartości kulturowych układu przestrzennego i zabudowy, z założenia obejmowały również analizę socjotopograficzną ${ }^{25}$, zawierającą rozplanowanie struktur rodzinnych i zawodowych warunków bytowych w istniejącej historycznej części miasta oraz postulatów mieszkańców (Kubiak 1983: 227).

${ }^{24}$ Studia stanowiły uzupełnienie ,Zasad ustalania szczegółowej problematyki opracowania miejscowych planów zagospodarowania przestrzennego" (wypracowanych w Ministerstwie Administracji, Gospodarki Terenowej i Ochrony Środowiska, załącznik do pisma z dnia 20 czerwca 1975 roku).

${ }^{25}$ Problem braku uwzględnienia partycypacji społecznej opracowanych „Wytycznych...” analizował Janusz Kubiak w „Uwagach dotyczących wytycznych do opracowania problematyki ochrony wartości kulturowych w planach zagospodarowania przestrzennego". Twierdził, że dzielnice zabytkowe miast są przestrzenią społeczną i należy je traktować ze szczególną wrażliwością antropogeniczną. „Jeśli mówimy użytkownik, znowu nieodmiennie mamy na myśli instytucję [...] i nie w pełni uświadamiamy sobie społeczeństwo jako użytkownika [...] konkretnych ludzi żyjących w bliższym lub dalszym otoczeniu zabytków czy, jak inni wolą, dóbr kultury”. 

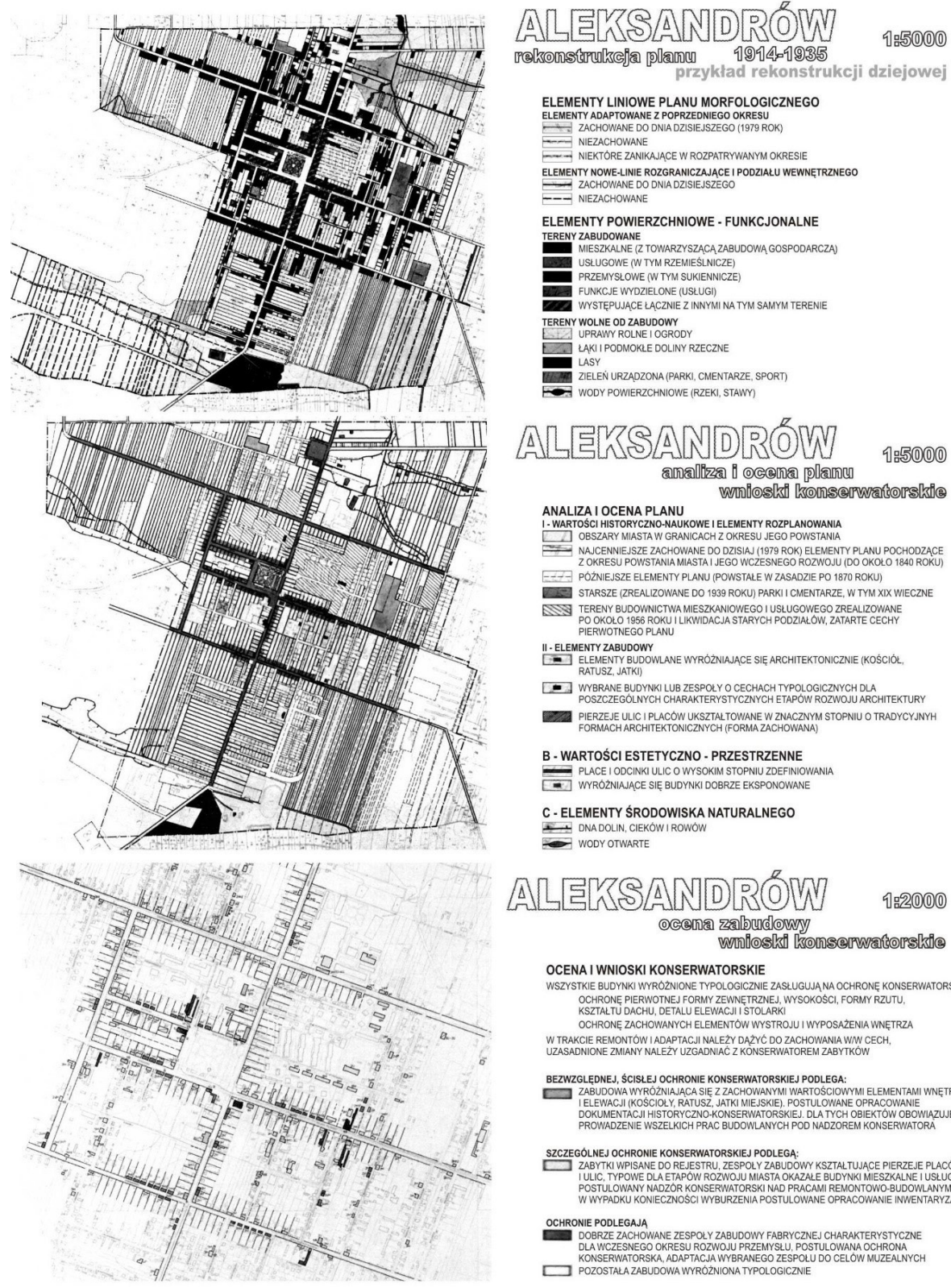

ELEMENTY LINIOWE PLANU MORFOLOGICZNEGO

ELEMENTY ADAPTOWANE $Z$ POPRZEDNIEGO OKRESU

-- NEZACHOWANE

N-A NEKTORE ZANIKAJAQCE WROZPATRYWANYM OKRESE

ELEMENTY NOWE-LINIE ROZGRANICZAJACEI PODZIAEU WEWNĘTRZNEGO

ZACHOWANE DO DNIA DZIIIEJSZEGO

ELEMENTY POWIERZCHNIOWE - FUNKCJONALNE

TERENY ZABUDOWANE MIESZKALNE (ZTOWARZYSZACAZABUDOWA GOSPODARCZA)

USLUGOWE (WTTMM RZEMIESINICZE)

PRZEMYSLOWE (N TYM SUKLENNICZE)

FUNKCJE WYDZIELONE (USLUG)

WYSTEPUJACE LACZNE Z INNYMI NA TYM SAMYM TERENIE

Y WOLNE OD ZABUDOWY

LAKII PODMOKLE DOLINY RZECZNE

LASY

ZIELEN URZADZONA,(PARKI, CMENTARZE, SPORT)

\section{AILEMSANDRO̊W

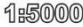

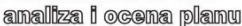

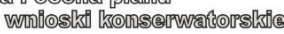

ANALIZA I OCENA PLANU

I- WARTOSCI HISTORYCZNO-NAUKOWE I ELEMENTY ROZPLANOWANIA

NAJCENNIEJSZE ZACHOWANE DO DZISAJ (1979 ROK) ELEMENTY PLANU POCHODZACE 2OCH

DTS STPSZE TZREAUZO

L.

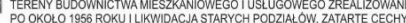
PIERNOTNEGO PLANU

II- ELEMENTY ZABUDOWY

- ELEMENTY BUDO

- WYBRANE BUDYNKI LUB ZESPOLY Y CECHACH TYPOLOGICZNYCH DLA

2C. PIERZEJE ULICI PLACOWW UKSZTALTOWANE W ZNACZNYM STOPNIU O TRADYCYJNYH

B - WARTOŚCI ESTETYCZNO - PRZESTRZENNE

PLACE IODCINKI ULIC OWYSOKIM STOPNIU ZDEFINIOWAN

PLACE I ODCINKI ULIC O WYSOKIM STOPNIU ZDEFINIO

C - ELEMENTY ŚRODOWISKA NATURALNEGO

DNADOLIN, CIEKOWI ROWOW

WODYOTWARTE

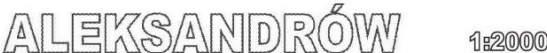 ๑Gอกล zอ|bud|owyy

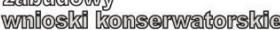

OCENA I WNIOSKI KONSERWATORSKIE

WSZYSTKIE BUDYNKI WYRÓŻNIONE TYPOLOGICZNEE ZASLUGUJA NA OCHRONĘ KONSERWATORSKA OCHRONE PERWOTNEJ FORMY ZEWNETRZNEJ, WYSOKOSCI, FORMY RZUTU,

KSZTALTU DACHU, DETALU ELEWACNII STOLARKI
OCHRONE ZACHOWANYH ELEMENTOW WYSTROJUI WYPOSAZENIA WNETRZA W TRAKCIE REMONTOW I ADAPTACI NALEZY DAZYC DO ZACHOWANIA WIW CECH,

UZASACNIONE ZMIANY NAL ZT UZGADNIACZ KONSERWATOREM ZABY

BEZWZGLEDNEJ, SCISLEJ OCHRONIE KONSERWATORSKIEJ PODLEGA:
ZABUDOWA WROZZNAAACA SEZ ZZAAHOWANYMI WARTOSCIOWYMI ELEMENTAMI WNĘTRZA IELENACJ (KOSCIOLY, RATUSZ, JATKI MEJSKIE). POSTULOWANE OPRACOWANE DOKUMENTACUI HISTORYCZNO-KONSERWATORSKLE. DLATYCH OBIEKTOW OBOWIAZUJ

SZCZEGÓLNEJ OCHRONIE KONSERWATORSKIEJ PODLEG

ZABYTKI WPISANE DO REJESTRU, ZESPOLY ZABUDONY KSZTALTUJACE PIERZEJE PLACOW

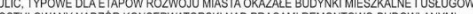
WWYPADKU KONIECZNOSCIWYBURZZNAA POSTULOWANE OPRACOWANIEINWENTARYZAGI

OCHRONIE PODLEGAJA

DOBRZE ZACHOWANE ZESPOLY ZABUDOWY FABRYCZNEJ CHARAKTERYSTYCZNE LA WCZESNEGO OKRESU ROZNOJU PRZEMYSLU, POSTULONANA OCHRONA $\square$ POZOSTALAZABUDOWAWYRÓŻNIONA TYPOLOGICZNIE

Ryc. 4. Studium historyczno-urbanistyczne wykonane dla miasta Aleksandrowa Łódzkiego - przykłady plansz tematycznych, Łódź 1979 r. Oprac. własne na podstawie oryginalnego dokumentu studium Źródło: Wytyczne Ośrodka Badań i Dokumentacji Zabytków oraz Biura Programowania i Projektowania Rozwoju Łodzi (zasoby Archiwum Wojewódzkiego Urzędu Ochrony Zabytków w Łodzi) 
Jak pokazuje analiza wykonanych dokumentacji, zakres analizujący rozwój antropogeniczny i potrzeby społeczne był w omawianym okresie, niestety, najmniej uwzględniany w procesie planowania (Kłosek-Kozłowska 2007). Brano pod uwagę natomiast treści programowo-przestrzenne, wśród których z punktu widzenia ochrony krajobrazu kulturowego istotne były: kompozycja kształtowania struktury miasta i kształtowania architektonicznego zabudowy (sylwety, wnętrza urbanistyczne, pierzeje ulic i placów), kształtowanie zieleni, elementy układu komunikacyjnego i infrastrukturalnego oraz zasady wyposażenia komunalnego (oświetlenie, reklamy, nawierzchnie).

Plan składał się z części opisowej oraz graficznej, w skład której wchodziły plansze przedstawiające koncepcję przestrzenną (przewidującą docelowy obraz zespołu staromiejskiego) oraz działania programowe (zawierające ofertowe określenie możliwości rozmieszczenia funkcji programu ogólnomiejskiego). Przesądzenia operacyjne konstruowane były jako podstawowy materiał dla programu realizacyjnego, który określał kolejność postępowania w stosunku do poszczególnych terenów i obiektów (konserwacja, adaptacja, wyburzenia, nowe realizacje), a także priorytety realizacji wynikające z uwarunkowań i współzależności poszczególnych elementów zagospodarowania i uzbrojenia terenu.

Należy podkreślić, że założenia przyjmowane na podstawie dokumentacji konserwatorsko-urbanistycznych zawierały słuszną metodologię działania - oprócz ustaleń merytorycznych zawierały również wskazania działań operacyjnych. Niestety, w warunkach centralistycznego zarządzania strukturami państwa oraz braku skrystalizowanych funduszy na ochronę dziedzictwa przestrzennego ustalenia przyjmowane w dokumentach planistyczno-konserwatorskich okazały się utopijne, pozostawiając praktykę daleko za badaniami, opracowaniami planistycznymi i potrzebami adaptacyjnymi. Główni realizatorzy prac konserwatorskich, którymi od lat 50. XX wieku były pracownie konserwacji zabytków, nie zdołali skutecznie wdrażać sprecyzowanych w planach założeń ochronnych w przestrzeniach miejskich. Nie służył temu również scentralizowany system budowlany, obowiązujące normy urbanistyczne i brak państwowych zachęt fiskalnych. Niewiele zmieniła również kolejna redakcja „Wytycznych konserwatorskich do planów zagospodarowania przestrzennego", która powstała w wyniku rządowego programu „Ratowanie miast historycznych", rozpoczętego w 1995 roku przez Ministerstwo Kultury. Był to jeden z pięciu programów badawczych (program IV), który jako jedyny uzyskał rangę programu rządowego, funkcjonującego do $1998 \mathrm{roku}^{26}$. Stanowił on wstęp do tworzenia współczesnych zasad rewitalizacji polskich miast.

${ }^{26}$ Protokół obrad komisji poruszającej problemy odbudowy miast zabytkowych zamieszczono w Biuletynie nr 3518/II Komisji Kultury i Środków Przekazu (155) z 22 kwietnia 1997 roku. Rządowy program „Ratowanie miast historycznych” kierowany był przez architekta Janusza Stępkowskiego. Wyniki prac programowych były propozycją zmian ustawowych, zakładających renowację i modernizację zabudowy miejskiej 


\section{Współczesne formy ochrony obszarowej miast}

Strefy ochrony konserwatorskiej zostały wprowadzone w legislacji polskiej dopiero w 1990 roku. W nowelizacji ustawy o ochronie dóbr kultury ${ }^{27}$ wskazano, że pod względem rzeczowym przedmiotem ochrony może być krajobraz kulturowy w formie ustanowionych stref ochrony konserwatorskiej. Oznaczało to, że dzięki ustanowieniu takich stref można wprowadzać zasady ochrony i właściwej kreacji na obszarach zabytkowych miast. Niestety, nie opracowano aktu wykonawczego do przepisów, czyli odpowiedniego rozporządzenia, które określałoby sposób klasyfikacji oraz dopuszczony zakres ochrony konserwatorskiej w ustanawianych obszarach. Poprawność przesądzeń oraz ich szczegółowość uzależniono od woli autora dokumentu planistycznego. Wprowadzone w planach obszarowe formy ochrony, a w nich konserwatorskie zasady działania obowiązywały w dokumentach planistycznych do 2003 roku. Miało to duże znaczenie na terenach o wartościach kulturowych, w szczególności w granicach zespołów staromiejskich oraz obszarach, w których dominował krajobraz otwarty. Niestety, w 2003 roku wprowadzono abolicję wszystkich ogólnych planów miejscowych, których treść była opracowywana na mocy przepisów o planowaniu przestrzennym z $1984 \mathrm{roku}^{28}$. Prawna eliminacja obowiązujących planów spowodowała likwidację rzeczywistego funkcjonowania stref ochronnych przyjmowanych dotychczas w tych dokumentach. Do dzisiaj wiele miejsc o szczególnych wartościach

w formie gminnych programów operacyjnych. Do 1997 roku szczególną opieką objęto 13 zespołów staromiejskich. Do programu zgłosiło się ponad 120 miast, licząc na pomoc w pracach, które miały charakter interwencyjny. Minister kultury i sztuki uruchomił specjalne fundusze, przeznaczając dla tych miast w sumie 88 mld starych złotych. Pieniądze te były użyte głównie na realizację badań naukowo-konserwatorskich i częściowo na sporządzenie dokumentacji technicznej.

${ }^{27}$ Ustawa z dnia 15 lutego 1962 roku o ochronie dóbr kultury i o muzeach (Dz.U., nr 10, poz. 48) oraz jej nowelizacja z 1990 roku - Ustawa z dnia 19 lipca 1990 roku o zmianie ustawy o ochronie dóbr kultury i o muzeach (Dz.U., nr 56, poz. 322). Nowelizacja z 1990 roku w art. 5, pkt 12 ustawy wprowadziła jako kolejną formę ochrony konserwatorskiej krajobraz kulturowy w formie ustanawianych stref ochrony konserwatorskiej, rezerwatów i parków kulturowych.

${ }^{28}$ Ustawa z dnia 7 lipca 1994 roku o zagospodarowaniu przestrzennym (Dz.U., nr 89, poz. 415), w art. 77 przyjmowała: miejscowe plany zagospodarowania przestrzennego, obowiązujące w dniu wejścia w życie ustawy, tracą moc po upływie 5 lat od dnia jej wejścia w życie (od 1 stycznia 1995 roku). Następnie czas na opracowanie nowych planów wydłużono Ustawa z dnia 21 grudnia 2001 roku o zmianie ustawy o zagospodarowaniu przestrzennym (Dz.U., nr 154, poz. 1804), w art. 1 przejęto: w ustawie z dnia 7 lipca 1994 roku [...] wyrazy „5 lat” zastępuje się wyrazami „8 lat”. W efekcie w ciągu 8 lat jedynie niewielka część miast i gmin opracowała nowe dokumenty planistyczne. Znaczna większość pozostała bez sprecyzowanych kierunków rozwoju i zasad zagospodarowania. 
przestrzennych nie posiada obowiązującego prawa lokalnego, co oznacza brak spójnych zasad ochronnych i nadzoru nad procesami budowlanymi.

Obecnie samorządy miejskie mają możliwość kształtowania własnej polityki przestrzennej. Główne podstawy prawne to ${ }^{29}$ : obowiązująca od 2003 roku, wielokrotnie nowelizowana ustawa o planowaniu i zagospodarowaniu przestrzennym, ustawa o rewitalizacji, stanowiąca kanwę działań operacyjnych oraz ustawa potocznie nazywana krajobrazową, na mocy której samorządy mogą regulować politykę reklamową i działania związane z kształtowaniem małej architektury w mieście. Krajobraz kulturowy kreuje się w różnych skalach: od poziomu całego miasta w kierunkowym dokumencie Studium uwarunkowań i kierunków zagospodarowania przestrzennego, do poziomu fragmentu struktury przestrzennej w prawie miejscowym w postaci planu zagospodarowania oraz $\mathrm{w}$ dokumencie planu rewitalizacji, który pozwala również na określanie działań realizacyjnych w partnerstwie publicznoprawnym. Odrębnym prawem lokalnym może być Kodeks krajobrazowy lub Uchwała krajobrazowa, w której miasto może określić zasady kształtowania nośników reklamowych oraz zakres regulacji finansowych związanych z ich lokalizacją. Kompetencje ochrony i kreacji obszarowej posiadają obecnie samorządy, które własny sposób zarządzania przestrzenią wprowadzają w życie poprzez ustalenia w dokumentach prawa na poziomie lokalnym.

Zasady ochrony obszarowej określa się w miejscowych planach zagospodarowania przestrzennego ${ }^{30}$, w których ustala się nakazy, zakazy lub dopuszczenia działań budowlanych w pojedynczych budynkach o wartościach kulturowych lub w większej skali planistycznej (ryc. 8). Ustalenia dotyczące zasad ochrony dziedzictwa kulturowego i zabytków mogą obejmować również określenie zagospodarowania i użytkowania terenów. Odnosić się to może do zasobów budowlanych, układu przestrzennego, elementów zielonych oraz struktury podziału na działki budowlane. W planach miejscowych ustanawia się niekiedy również strefy gwarantujące właściwą ekspozycję istniejących zabytków, wprowadza nakazy zachowania wglądów widokowych oraz kształtuje wysokości zabudowy, które sankcjonują historyczną kompozycję układu przestrzennego. Zasady przyjęte w miejscowych planach zagospodarowania przestrzennego stanowią prawo i są

${ }^{29}$ Ustawa z dnia 27 marca 2003 roku o planowaniu $i$ zagospodarowaniu przestrzennym (Dz.U., nr 80, poz. 717 wraz z późn. zm.); Ustawa o rewitalizacji z dnia 9 października 2015 roku (Dz.U., 2015, poz. 1777 wraz z późn. zm.); Ustawa o zmianie niektórych ustaw w związku ze wzmocnieniem narzędzi ochrony krajobrazu z dnia 24 kwietnia 2015 roku (Dz.U., 2015, poz. 774 wraz z późn. zm.).

${ }^{30}$ Rozporzadzenie Ministra Infrastruktury z dnia 26 sierpnia 2003 roku w sprawie wymaganego zakresu projektu miejscowego planu zagospodarowania przestrzennego określa w $\S 4$, ust. 4 obowiązek ustalania zasad ochrony dziedzictwa kulturowego i zabytków oraz dóbr kultury współczesnej, które zawierają określenia obiektów i terenów chronionych, w tym określenie nakazów, zakazów, dopuszczeń i ograniczeń w zagospodarowaniu tych terenów (Dz.U., nr 80, poz. 717). 
podstawą do określania wytycznych w pozwoleniach na budowę. Mimo że nie ma obecnie prawnego obowiązku wykonywania szczegółowych dokumentacji konserwatorskich $\mathrm{w}$ procesie planistycznym, na potrzeby planu często opracowuje się analizy i waloryzacje określające szczegółową ewolucję układów przestrzennych i ich składowych. Umożliwia to dokładną identyfikację elementów, które zachowały się w istniejącej strukturze miasta. Znajomość historycznego rozwoju jest konieczna w procesie podejmowania decyzji oraz $\mathrm{w}$ określaniu i ocenie działań przestrzennych (ryc. 5 i 6). Badania nawarstwień w tkance miasta wykonuje się na potrzeby zmian wprowadzanych zarówno w zabytkowych zespołach (Cysek-Pawlak, Krzysztofik 2018), jak i w przekształceniach całych dzielnic (Cysek-Pawlak 2018; Denis 2020; Tomczak, Krzysztofik 2020).

Istnieje również możliwość opracowania dla fragmentów miasta miejscowych planów rewitalizacji ${ }^{31}$, których ustalenia obejmować mogą dokładne zasady kompozycji przestrzennej. Można je opracowywać na terenie, dla którego wyznaczono wcześniej Specjalną Strefę Rewitalizacji, w której proces planistyczny wzmocniony jest dodatkowo możliwościami przekształceń operacyjnych. Plany rewitalizacji pozwalają na ustalenie minimalnych i maksymalnych różnic w wysokości sąsiadujących budynków, zasad kształtowania form budowlanych z uwzględnieniem wskazanych do zachowania cech charakterystycznych oraz szczegółowych regulacji w zakresie kształtowania przestrzeni publicznych.

W miejscowych planach rewitalizacji można określić wzajemne proporcje i kształty brył, poziom posadowienia parteru w budynkach, dopuszczalne wielkości i proporcje otworów okiennych oraz drzwiowych, podcienia i przeszklenia w elewacjach, a także zasady stosowania i eksponowania zewnętrznych elementów konstrukcyjnych i zdobniczych. Szczegółowo można opisać również lokalizację i rodzaj zieleni, w tym formę nasadzeń, dopuszczalny lub zakazany rodzaj gatunków roślin, a nawet wysokość zieleni i pełnione przez nią funkcje. Dokładność kształtowania ładu przestrzennego ma znaczenie w miejscach o wysokim stopniu zachowania dziedzictwa kulturowego, a możliwe do określenia działania operacyjne dają podstawę do rzeczywistych przekształceń zabytkowej struktury miasta. Mogą mieć one formę umów prywatno-publicznych, w których za część procesu realizacyjnego odpowiadają podmioty prywatne. Daje to efekt synergii $\mathrm{w}$ procesie przekształcania miasta na terenach wymagających interwencji przestrzenno-społecznych. Wiążą się z tym również przyjmowane w specjalnych strefach rewitalizacji instrumenty fiskalne i administracyjne, np. dotacje na remonty budynków, prawo pierwokupu czy ulgi podatkowe. Konsekwentnie realizowane dają nadzieję na faktyczne przekształcenia przestrzenne i odnowę obszarów zdegradowanych w miastach i gminach.

${ }^{31}$ Rozporzadzenie Ministra Infrastruktury i Budownictwa z dnia 1 lipca 2016 roku w sprawie zakresu projektu miejscowego planu rewitalizacji części tekstowej oraz zakresu i formy wizualizacji ustaleń miejscowego planu rewitalizacji (Dz.U., poz. 1032). 


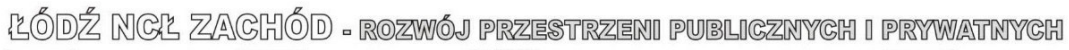

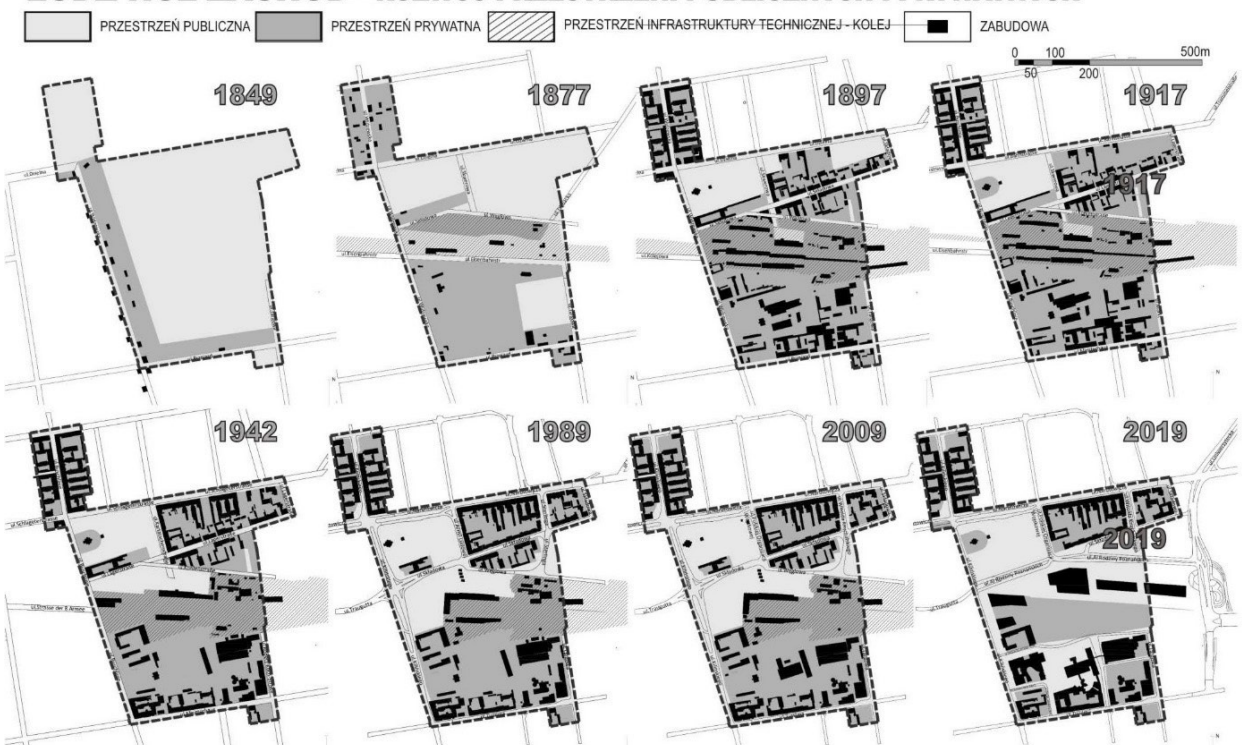

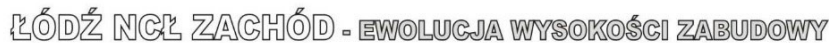

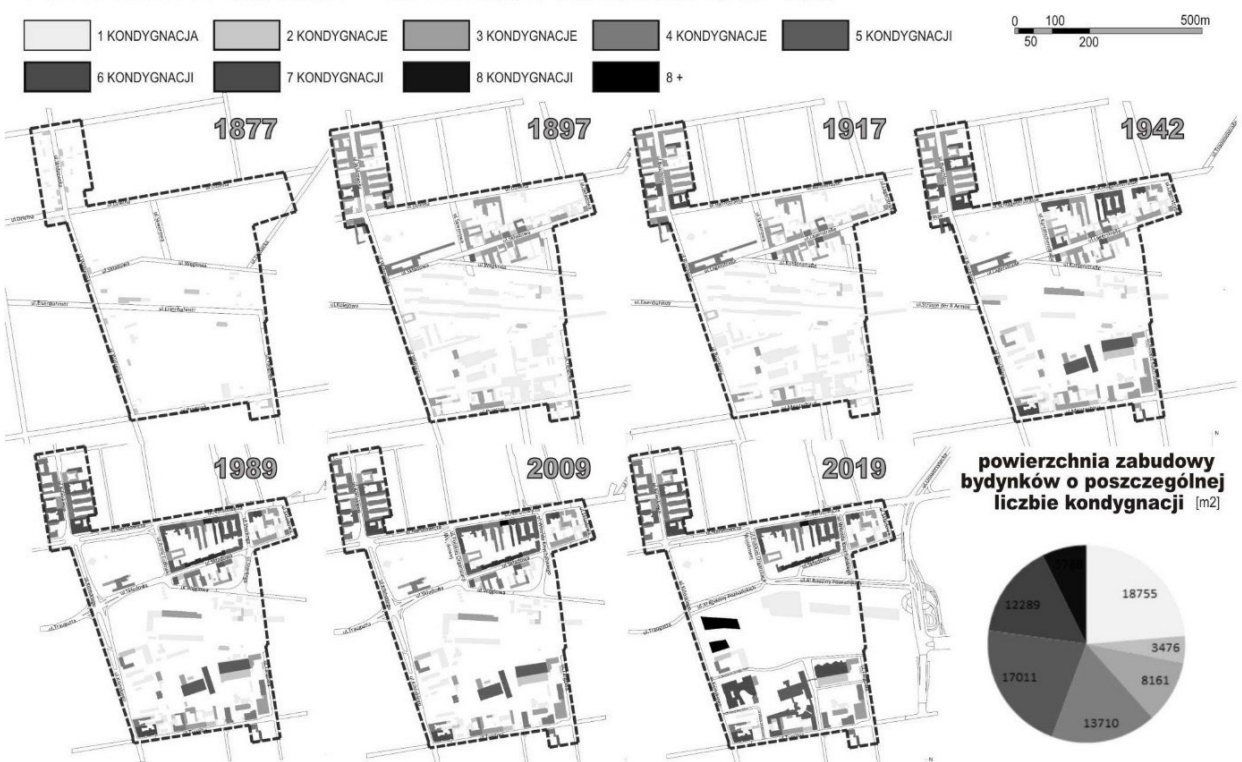

Ryc. 5. Badania rozwoju przestrzennego fragmentu miasta Łodzi - „Etapy rozwoju granic przestrzennych oraz ewolucja wysokości zabudowy”. Rewitalizacja obszarowa nr 3 - teren obejmujący zachodnią część Nowego Centrum Łodzi. Badania prowadzone na Politechnice Łódzkiej w ramach programu „Ewaluacja przestrzenno-funkcjonalna procesów rewitalizacji” w Zespole Rewitalizacji i Projektowania Struktur Miejskich, Łódź 2020 


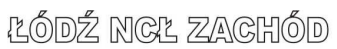

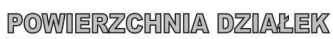
BUDOWLANYGU
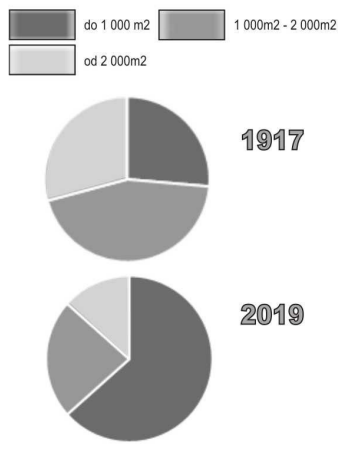

โอ17

2019
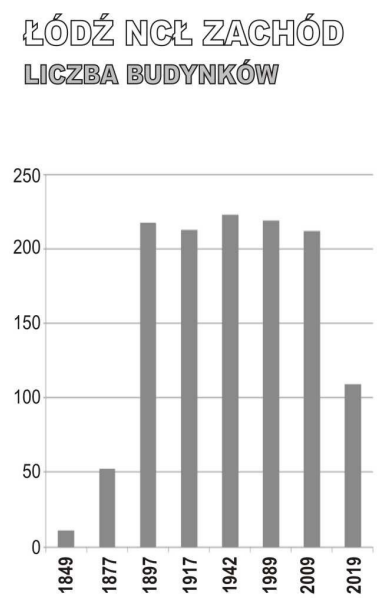

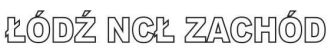

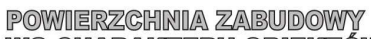

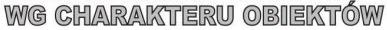

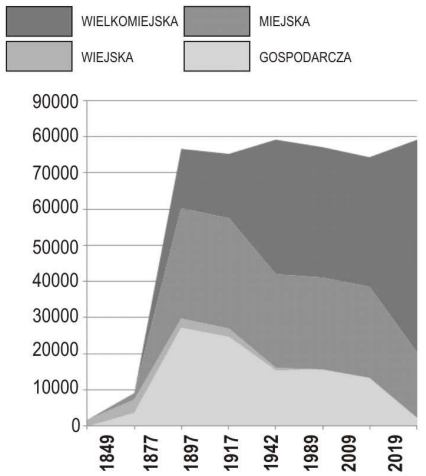

Ryc. 6. Wskaźniki rozwoju przestrzennego fragmentu miasta Łodzi - „Powierzchnia działek budowlanych, ilość budynków, charakter zabudowy”. Rewitalizacja obszarowa nr 3 - teren obejmujący zachodnią część Nowego Centrum Łodzi. Badania prowadzone na Politechnice Łódzkiej w ramach programu „Ewaluacja przestrzenno-funkcjonalna procesów rewitalizacji”

w Zespole Rewitalizacji i Projektowania Struktur Miejskich, Łódź 2020

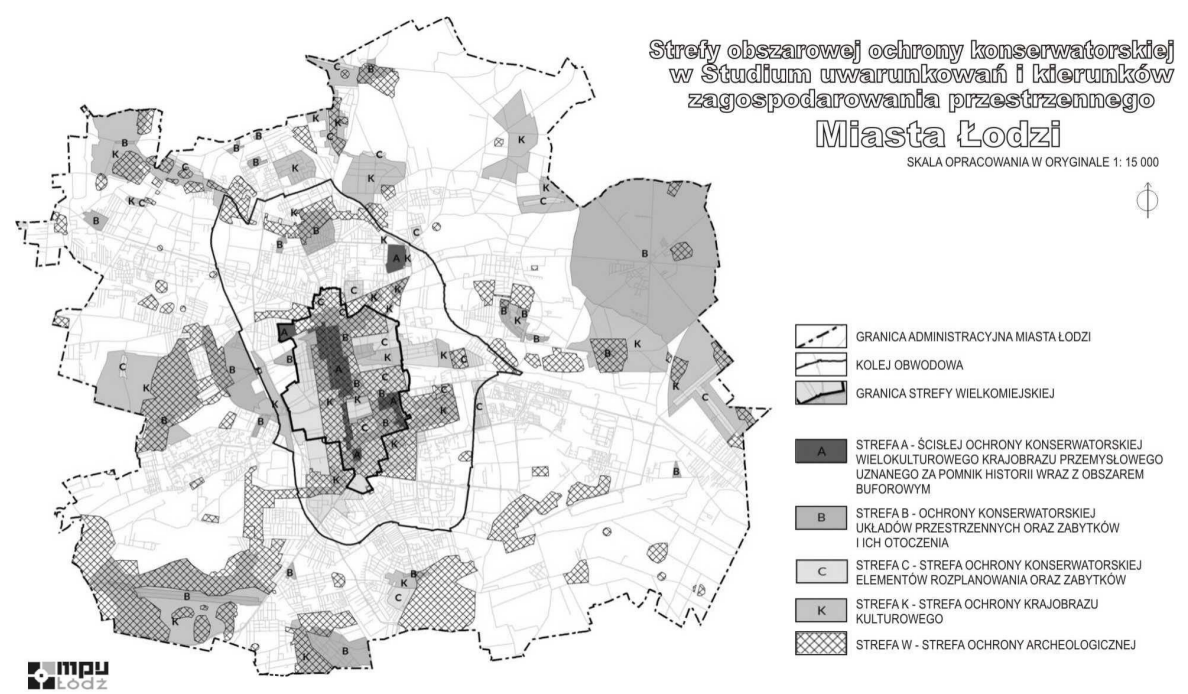

Ryc. 7. Obszarowe strefy ochrony konserwatorskiej wyznaczone we współczesnym Studium uwarunkowań i kierunków zagospodarowania przestrzennego miasta Łodzi.

Ochroną objęto krajobraz kulturowy miasta, historyczny układ przestrzenny oraz dziedzictwo archeologiczne. Na podstawie planszy: Dziedzictwo kulturowe, zabytki oraz dobra kultury współczesnej

Źródło: Miejska Pracownia Urbanistyczna w Łodzi (2018) 
Zasady ustalane w planach miejscowych i planach rewitalizacji muszą być zgodne z polityką przestrzenną określaną w dokumencie nazywanym Studium uwarunkowań i kierunków zagospodarowania przestrzennego. Nie ma on mocy prawnej, ale jego ustalenia są wiążące przy kreowaniu polityki miejscowej, w tym określaniu działań ochronnych na terenie obszarów zabytkowych. W studium definiuje się zakres terytorialny polityki ochronnej oraz wprowadza strefy ochrony konserwatorskiej, a w nich ustala się generalne zasady działania w zakresie kształtowania układów przestrzennych, elementów rozplanowania struktury miejskiej, ochrony krajobrazu kulturowego i archeologii (ryc. 7).

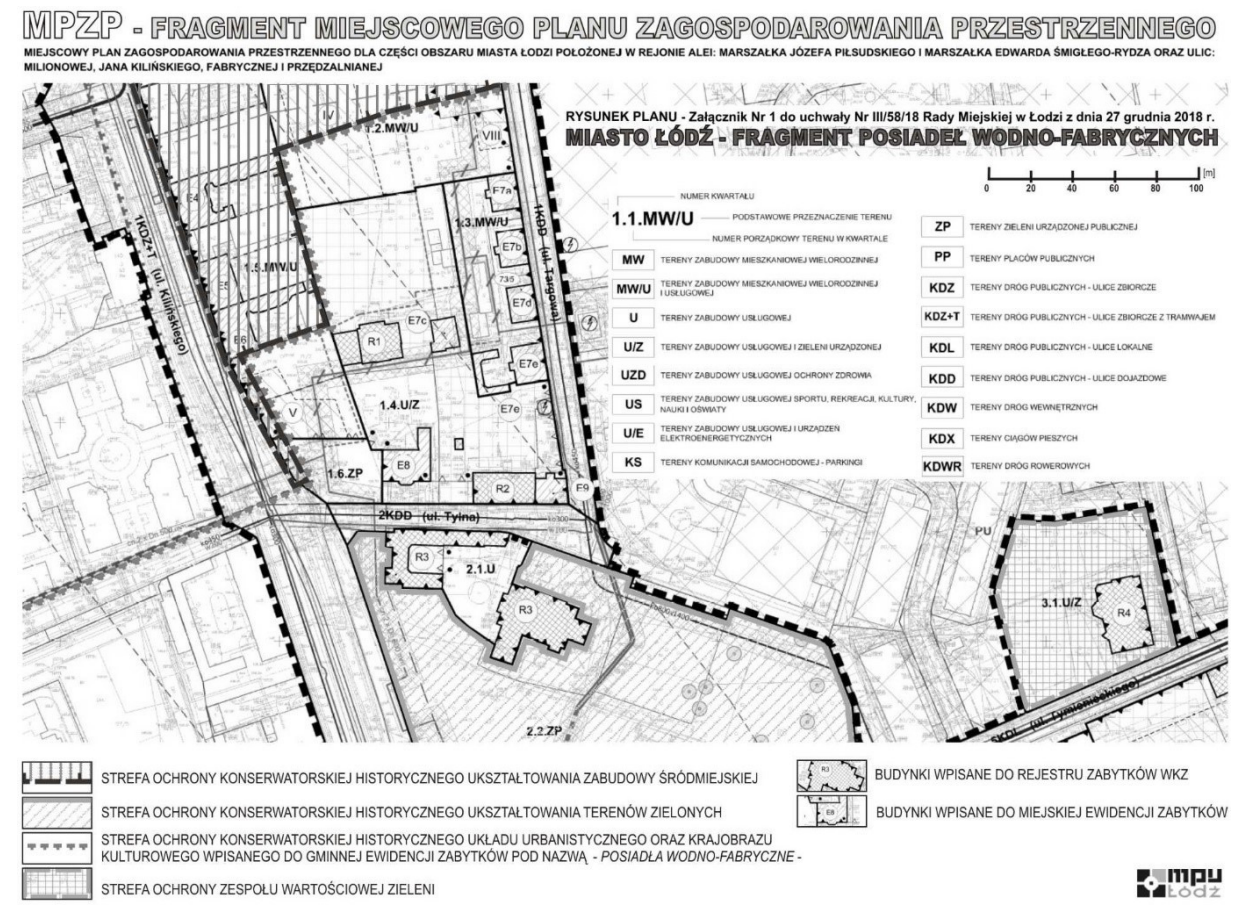

Ryc. 8. Fragment miejscowego planu zagospodarowania przestrzennego dla fragmentu miasta Łodzi (Dz.U. Woj. Łódzkiego z dnia 18 stycznia 2019 roku, poz. 417).

W planie wskazano ochronę pojedynczych budynków zabytkowych oraz obszarowe strefy ochrony konserwatorskiej

Źródło: Miejska Pracownia Urbanistyczna w Łodzi (2019)

Polska legislacja, oprócz szczegółowych zasad ochrony i kreacji określanych w procesie planowania, wprowadza również inne obszarowe formy ochrony dziedzictwa kulturowego, takie jak pomnik historii i park kulturowy. Pomnik historii jest najwyższą polską formą ochrony dziedzictwa kulturowego, nadawaną przez Prezydenta Rzeczypospolitej Polskiej. Jest to szczególny sposób nobilitacji obszaru o wartościach kulturowych, polegający głównie na akcentowaniu prestiżu 
miejsca w skali całego kraju. Objęcie obszaru tą formą ochrony konserwatorskiej poprzedzone jest nałożeniem na dany zabytek innej lokalnej formy ochrony w postaci wpisu do rejestru zabytków lub ustanowienia parku kulturowego. Pomnik historii może być przedsionkiem do ubiegania się o wpis na listę Światowego Dziedzictwa Kultury UNESCO. Ochronę obszaru zabytkowego można ustanowić również na poziomie samorządowym w formie tzw. parku kulturowego. Ta forma ma na celu zachowanie zarówno historycznej substancji zabytkowej, jak i przestrzeni ją otaczającej. Daje to możliwości ochrony zabytków o dużej skali odbioru, szczególnie całych zespołów zabudowy śródmiejskiej, ale także przestrzeni o szczególnych wartościach przyrodniczo-kulturowych. Na obszarach, na których ustanowiono park kulturowy, działania przestrzenne prowadzone są w oparciu o plan ochrony parku, służący praktycznej realizacji celów ochrony zarówno w odniesieniu do zasobów krajobrazu (zagospodarowania terenu), jak i działań i procesów tam zachodzących (zarządzania parkiem).

\section{Podsumowanie}

Historia ochrony polskiego krajobrazu miejskiego jest różnorodna i wielowątkowa. Poszukiwanie dróg nowej urbanistyki oraz tworzenie zasad ochrony miast historycznych rozpoczęło się już w okresie międzywojennym. Poprzedzała je działalność stowarzyszeń i organizacji funkcjonujących w czasach zaborów, która zapoczątkowała kształtowanie i ustanawianie zasad ochrony w odradzającym się po 1918 roku państwie polskim. Okres dwudziestolecia międzywojennego stanowi ważny etap w dynamicznym rozwoju miast, charakteryzujący się poszukiwaniem równowagi pomiędzy ochroną wartości istniejących w strukturze zabudowy a dążeniem do technicznej modernizacji miast zabytkowych. Za formalny początek kształtowania się zasad polskiej ochrony obszarowej krajobrazu miejskiego należy uznać Dekret Regencyjny z 1918 roku, w którym pojawiło się postrzeganie zabytków w ujęciu przestrzennym i widokowym. W prawie polskim wprowadzono pojęcia określające odległość wizualną, prawo widoku na zabytek oraz służebność krajobrazową. Po raz pierwszy rozpoczęto również działania mające na celu identyfikację najważniejszych elementów przestrzennych w strukturze miast. Efektem tych działań była próba utworzenia w 1936 roku wykazu miejscowości, w których krajobraz zasługiwał na ochronę. Okres ten przyniósł też pierwsze spisy inwentaryzacyjne historycznych miast i miasteczek oraz pierwsze wstępne studia historyczne uwzględniające układ i krajobraz zespołów staromiejskich. Rosła świadomość potrzeby ochrony obszarowej w zawodowych kręgach konserwatorskich i urbanistycznych. Należy zwrócić uwagę, że działo się to w czasie, kiedy w architekturze królowała doktryna modernistyczna, a myślenie o zachowaniu historycznych wartości przestrzennych konkurowało z silnym kierunkiem nowoczesnej awangardy. 
Na początku okresu powojennego, po roku 1946, problemem okazał się duży niedostatek znajomości stanu i liczby zachowanych zabytków. Akcja porządkowania zasobów rozpoczęła się już w latach 50 . XX wieku od opracowywania spisów inwentarzowych oraz tek urbanistycznych, w których zamieszczono m.in. informacje o wartościach przestrzennych zespołów czy układów miejskich. Ochrona konserwatorska stała się elementem składowym opracowań planistycznych. Kształtowanie przestrzeni w planach poprzedzano studiami historyczno-urbanistycznymi lub konserwatorsko-urbanistycznymi, w których badano ewolucję rozwoju miast oraz określano elementy niezbędne do zachowania w strukturze przestrzennej. Okres powojenny przyniósł także wypracowanie metodyki ochronnej w postaci ustanawiania stref konserwatorskich w dokumentach planistycznych. Pełniły one rolę obszarowego zabezpieczenia istniejących wartości przestrzennych. Usankcjonowano je jednak dopiero w 1990 roku w prawie ochrony zabytków. Okres powojenny to czas wielu dobrych praktyk oraz prób łączenia działań konserwatorskich i urbanistycznych. Wypracowane metody wdrażania problematyki ochrony wartości kulturowych do planów zagospodarowania przestrzennego są aktualne również dzisiaj. Niestety, realizacja założeń projektowych w ówczesnych warunkach centralnego zarządzania strukturami państwa oraz braku wystarczających funduszy na ochronę dziedzictwa przestrzennego nie zawsze była zgodna z przyjętymi zasadami ochrony.

Współcześnie strefy ochrony krajobrazu kulturowego występują w opracowaniach określających kierunki rozwoju miast oraz są wdrażane w dokumentach miejscowych planów zagospodarowania przestrzennego. Prawo lokalne pozwala precyzyjnie określić historyczne elementy struktury zabudowy i układu, które należy chronić przed niepożądanymi przekształceniami. Dokładne zasady ochrony i kreacji określić można również w dokumentach rewitalizacyjnych, planach zarządzania dla parków kulturowych oraz w innych obszarowych formach ochrony konserwatorskiej.

Właściwa ochrona autentyzmu i wartości historycznych struktur przestrzennych jest bardzo ważna i powinna stanowić element harmonijnego rozwoju miast. Ma to szczególne znaczenie w Europie Środkowej i Wschodniej, gdzie długotrwała stagnacja powojenna sprzyjała zachowaniu miast, które uniknęły zniszczeń wojennych oraz powojennej modernistycznej degradacji i zachowały rozplanowanie przestrzenne z czytelnymi fazami rozwojowymi oraz historyczną zabudową.

\section{Literatura}

Andrulewicz H., 1968, Konferencja urbanistyczna poświęcona założeniom oraz kryteriom oceny wartości zabytkowej zespołów miejskich - Warszawa 22 XI 1967, „Ochrona Zabytków", 1: 55-58.

Bodek M., 1935, Polskie prawo budowlane. Zbiór ustaw i rozporzadzeń z zakresu ustawodawstwa budowlanego. Obszerny skorowidz alfabetyczny, Księgarnia Nakładowa, Lwów. 
Cysek-Pawlak M., 2018, Mixed use and diversity as a New Urbanism principle guiding the renewal of post-industrial districts. Case study of the Paris Rive Gauche and the New Centre of Lodz, „Urban Development Issues”, 57: 53-62.

Cysek-Pawlak M., Krzysztofik S., 2018, The new urbanism of quality architecture and urban design versus place identity. A case of val d'Europe and the Manufaktura complex, „European Spatial Research and Policy”, 25/2: 99-115.

Denis M., 2020, Odzyskiwanie terenów poprzemysłowych nadrzecznych na przykładzie Frankfurtu nad Menem i Warszawy, „Przestrzeń i Forma”, 43: 147-162.

Drexler I., 1921, Odbudowanie wsi i miast na ziemi naszej, Wydawnictwo Zakładu Narodowego im. Ossolińskich, wydanie wtórne, Lwów-Warszawa-Kraków.

Feliński R., 1916, Budowa miasta z ilustracjami i planami miast, Nakładem Księgarni Gubrynowicza i Syna, Lwów.

Karczewski A., 1931, Ochrona zabytków architektury i przyrody, [w:] Zagadnienia urbanistyki w Polsce: Sprawozdanie z I-ej Konferencji Towarzystwa Urbanistów Polskich, „Dom-Osiedle-Mieszkanie”, 25: 24-28.

Kłosek-Kozłowska D., 2007, Ochrona wartości kulturowych miast a urbanistyka, Oficyna Wydawnicza Politechniki Warszawskiej, Warszawa.

Kowalczyk J., 1978, Powołanie i działalność Towarzystwa Opieki nad Zabytkami Przeszłości z perspektywy siedemdziesięciu lat, „Ochrona Zabytków”, 31/2: 99-103.

Kubiak J., 1983, Uwagi dotyczace wytycznych do opracowania problematyki ochrony wartości kulturowych $w$ planach zagospodarowania przestrzennego, ,Ochrona Zabytków", 36: 226-229.

Lewicki J., 1999, Inwentaryzacja zabytków w okresie dwudziestolecia międzywojennego, „Ochrona Zabytków”, 4: 375-390.

Lewicki J., 2016, Regulacja i odbudowa miast Galicji jako źródło nowoczesnej teorii urbanistycznej w Europie Środkowej, [w:] Barańska I., Górzyński M. (red.), Odbudowy $i$ modernizacje miast historycznych $w$ pierwszej połowie dwudziestego wieku w Europie, Kaliskie Towarzystwo Przyjaciół Nauk, Kalisz: 107-143.

Manganowa I., 1952, Ogólnopolski Zjazd Konserwatorów, „Ochrona Zabytków”, 4: 281-286.

Maliszewski P., Andrulewicz H., Łotysz A., 1971, Dziat zabytków Architektury i Urbanistyki. Ogólna charakterystyka działu, „Ochrona Zabytków”, 24: 234-244.

Pawłowski K., Witwicki M., 1973, Wartość zabytkowa zespołów miejskich a zakres ich ochrony, [w:] Goldzamt E. (red.), Miasto a oblicze czasu, Arkady-Strojizdat, Warszawa-Moskwa: 173-185.

Pruszyński J., 1988, Organizacja ochrony zabytków w dwudziestoleciu międzywojennym, „Ochrona Zabytków”, 2: 75-85.

Pruszyński J., 1989, Ochrona zabytków w Polsce. Geneza, organizacja, prawo, Państwowe Wydawnictwo Naukowe, Warszawa.

Rymaszewski B., 1984, O przetrwanie dawnych miast, Arkady, Warszawa.

Szymaniec P., 2017, Polska myśl konserwatorska przełomu XIX i XX w. a rozwiazania Dekretu rady regencyjnej z dnia 31 października 1918 roku o opiece nad zabytkami 
sztuki i kultur, [w:] Różański M. (red.), Ochrona dóbr kultury w rozwoju historycznym, KPP Monografie, Olsztyn: 25-48.

Szymkiewicz G., 1938, Komentarz do Prawa budowlanego w nowym brzmieniu, [dział] Zewnętrzny wygląd budynków, nakład własny, Warszawa.

Śmigielski W., 1936, Sporzadzanie planu zabudowania dzielnic zabytkowych, „Biuletyn Urbanistyczny", IV(3): 28-33.

Tomczak A.A., 2018, Otwarty krajobraz kulturowy z zabytkiem w tle. Formy ochrony na przykładach z ziemi łódzkiej, Wydawnictwo Politechniki Łódzkiej, Łódź.

Tomczak A., Krzysztofik S., 2020, Integrated change planning in the historic postindustrial area in the centre of the city. A case study of riverside industrial complexes in Lodz, „Proceedings of the 56 ${ }^{\text {th }}$ World Planning Congress”: 782-791.

Witwicki M., 1966, Ewidencja miast zabytkowych, „Ochrona Zabytków”, 4: 33-38.

Wojciechowski J., 1920, Opieka nad zabytkami i ich konserwacja, Wydawnictwo Ministerstwa Sztuki i Kultury, Warszawa.

Zachwatowicz J., 1946, Program i zasady konserwacji zabytków, „Biuletyn Historii Sztuki i Kultury", Państwowy Instytut Historii Sztuki Inwentaryzacji Zabytków oraz Zakład Architektury Polskiej i Historii Sztuki Politechniki Warszawskiej, VIII(1/12): 49-54.

Zalasińska K., 2010, Prawna ochrona zabytków nieruchomych w Polsce, Wolters Kluwer Polska, Warszawa.

Zarębska T., 1973, Studia historyczno-urbanistyczne do planów zagospodarowania przestrzennego starych miast, [w:] Goldzamt E. (red.), Miasto a oblicze czasu, ArkadyStrojizdat, Warszawa-Moskwa: 160-172.

\section{Akty prawne}

Dekret Rady Regencyjnej o opiece nad zabytkami sztuki i kultury z 31 października 1918 roku (Dziennik Praw Państwa Polskiego z dnia 8 listopada 1918 r., nr 16, poz. 36).

Okólnik Ministerstwa Wyznań Religijnych i Oświecenia Publicznego nr 113 z dnia 24 października 1936 roku o ochronie charakteru miast starych i dzielnic staromiejskich, „Biuletyn Urbanistyczny”, marzec 1937 r., R. V, nr 1, ZMP i TUP, Warszawa 1937: 35-37.

Rozporzadzenie Ministra Infrastruktury z dnia 26 sierpnia 2003 roku w sprawie wymaganego zakresu projektu miejscowego planu zagospodarowania przestrzennego (Dz.U., nr 80, poz. 717).

Rozporzadzenie Ministra Infrastruktury i Budownictwa z dnia 1 lipca 2016 roku w sprawie zakresu projektu miejscowego planu rewitalizacji części tekstowej oraz zakresu i formy wizualizacji ustaleń miejscowego planu rewitalizacji (Dz.U., poz. 1032).

Rozporzadzenie Prezydenta Rzeczypospolitej z dnia 16 lutego 1928 roku o prawie budowlanym i zabudowaniu osiedli (Dz.U., nr 23, poz. 202).

Rozporzadzenie Prezydenta Rzeczypospolitej z dnia 6 marca 1928 roku o opiece nad zabytkami (Dz.U., nr 29, poz. 265). 
Ustawa z dnia 31 stycznia 1961 roku o planowaniu przestrzennym (Dz.U., $\mathrm{nr}$ 7, poz. 47).

Ustawa z dnia 15 lutego 1962 roku o ochronie dóbr kultury i o muzeach (Dz.U., nr 10, poz. 48).

Ustawa z dnia 19 lipca 1990 roku o zmianie ustawy o ochronie dóbr kultury i o muzeach (Dz.U., nr 56, poz. 322).

Ustawa z dnia 7 lipca 1994 roku o zagospodarowaniu przestrzennym (Dz.U., $\mathrm{nr}$ 89, poz. 415).

Ustawa z dnia 21 grudnia 2001 roku o zmianie ustawy o zagospodarowaniu przestrzennym (Dz.U., nr 154, poz. 1804).

Ustawa z dnia 27 marca 2003 roku o planowaniu i zagospodarowaniu przestrzennym (Dz.U., nr 80, poz. 717 wraz z późn. zm.).

Ustawa z dnia 24 kwietnia 2015 roku o zmianie niektórych ustaw w zwiazku ze wzmocnieniem narzędzi ochrony krajobrazu (Dz.U., 2015, poz. 774 wraz z późn. zm.).

\title{
Evolution of the principles of area protection of the urban landscape in Polish planning activities
}

\begin{abstract}
This chapter presents the most important stages in creating the principles of area protection in urban development documents. The creation of legal grounds and applied practices started from the moment Poland regained its independence, i.e. from the beginning of the interwar period, characterised by an intensification of efforts to formally sanction the protection of national heritage. In the post-war period, historical and urban studies were important, documenting the stages of development of settlement units and placing a value on their cultural worth. A breakthrough in the protection of the historic structure of cities occurred in the 1960s and 1970s, when area-based conservation zones and the principles of creating development guidelines for formal planning documents were introduced in urban planning practice. The area-based approach is also present in contemporary urban development directions and in the rules for the preparation of local zoning plans and revitalisation plans.
\end{abstract}

Keywords: city landscape, cultural heritage, spatial planning.

Dr inż. arch. Anna Aneta Tomczak

Politechnika Łódzka

Instytut Architektury i Urbanistyki

Wydział Budownictwa, Architektury i Inżynierii Środowiska

Zespół Rewitalizacji i Projektowania Struktur Miejskich

e-mail: aneta.tomczak@p.lodz.pl

(D) https://orcid.org/0000-0001-7436-5027 